\title{
PRODUÇÃO ESCRITA EM LIVROS DIDÁTICOS \\ DE ESPANHOL: UMA ANÁLISE DE COLEÇÕES \\ APROVADAS NO PNLD
}

\section{WRITTEN PRODUCTION IN SPANISH TEXTBOOKS: AN ANALYSIS OF COLLECTIONS APPROVED IN PNLD}

\section{Luciana Maria Almeida de Freitas Carolina Tovar Albuquerque ${ }^{* *}$}

\section{RESUMO}

Este artigo apresenta uma análise de livros didáticos de língua espanhola aprovados pelo Programa Nacional do Livro Didático (PNLD) e distribuídos aos estudantes de escolas públicas do país participantes do Programa. Mais especificamente, são examinadas as atividades de produção escrita em todas as coleções de espanhol que foram aprovadas nas quatro primeiras edições que incluíram o componente curricular Língua Estrangeira Moderna (inglês e espanhol), quais sejam: PNLD 2011 e 2014 (anos finais do Ensino Fundamental) e PNLD 2012 e 2015 (Ensino Médio). Dessa forma, busca-se construir uma série histórica de análise das obras aprovadas com foco em uma competência - a escrita que, segundo o edital do PNLD 2015, deve ser uma das priorizadas nos livros aprovados. Entende-se que esta pesquisa contribui para a promoção do conhecimento de questões relativas ao livro didático e à educação linguística em língua espanhola no Brasil, além de suscitar reflexões acerca de um Programa que alcança mais de 99\% das instituições escolares públicas do país. Como suporte teórico, lança-se mão do conceito de gênero discursivo segundo Bakhtin (2003) e Volóchinov (2017), e das contribuições de pesquisadores do texto e do discurso que vêm abordando o ensino da escrita em suas reflexões. Os resultados encontrados demonstram que as coleções aprovadas nos dois últimos editais analisados apresentaram propostas de produção escrita de qualidade superior, em uma compreensão mais próxima à da escrita como um processo que envolve a mobilização de inúmeros saberes linguísticos, genéricos e de mundo.

Palavras-chave: produção escrita; PNLD; língua espanhola.

\section{ABSTRACT}

This article presents an analysis of Spanish language textbooks approved by the Programa Nacional do Livro Didático (PNLD) and distributed to public school students in the country participating in the program. More specifically, written production activities are examined in all Spanish collections that were approved in the first four editions which included the Modern Foreign Language curriculum component (English and Spanish), which are:

\footnotetext{
* Universidade Federal Fluminense, UFF, Niterói, RJ, Brasil. lucianafreitas@id.uff.br Orcid: https://orcid.org/0000-0002-5124-0608

** Universidade Federal Fluminense, UFF, Niterói, RJ, Brasil. carolinatovar@id.uff.br Orcid: https://orcid.org/0000-0002-8671-0235
} 
PNLD 2011 and 2014 (final years of Elementary School) and PNLD 2012 and 2015 (High School). This way, it sought to build a historical series of analysis of the approved collections focusing on a specific competence - writing - that, according to the public announcement of PNLD 2015, should be one of the prioritized items in approved books. Thus, this research contributes to the promotion of knowledge about issues related to textbooks and language education in Spanish in Brazil, as well as to the reflection upon a Program that reaches more than 99\% of the country's public schools. As theoretical support, both the concept of discursive genre according to Bakhtin (2003) and Volóchinov (2017), and the contributions of researchers of the text and the discourse that include the teaching of writing in their reflections. The results show that the collections approved in the last two edicts analyzed presented higher quality proposals of written production, displaying an understanding of the competence which is closer to that of writing as a process involving the mobilization of numerous linguistic, generic and world knowledge.

Keywords: writing production; PNLD; Spanish language.

\section{PALAVRAS INICIAIS}

Em vez da versão de trechos de antologias, é preferível ensinar a redigir cartões postais, telegramas bilhetinhos, cartas, que são as coisas que o aluno precisará escrever em língua estranha.

(NASCENTES, 1928, p. 117)

Este artigo tem o objetivo de apresentar um projeto de pesquisa, já finalizado, que analisou as propostas de atividades de produção escrita em todas as coleções de espanhol aprovadas nas quatro primeiras edições do Programa Nacional do Livro Didático (PNLD) que incluíram o componente curricular Língua Estrangeira Moderna (inglês e espanhol): PNLD 2011 e 2014 (anos finais do Ensino Fundamental) e PNLD 2012 e 2015 (Ensino Médio). Assim, apresenta uma série histórica de análise das coleções aprovadas, observando possíveis avanços ocorridos nesses materiais didáticos, com foco em uma competência - a escrita - que, segundo o edital do PNLD 2015 (MEC/FNDE/SEB, 2013), deveria ser, juntamente com a leitura, priorizada nos livros de Língua Estrangeira.

Como suporte teórico para desenvolvimento da pesquisa, lançou-se mão, fundamentalmente, do conceito de gênero discursivo de acordo com o Círculo de Bakhtin (BAKHTIN, 2003; VOLÓCHINOV, 2017), e de trabalhos sob perspectivas discursivas ou textuais que abordam o ensino da escrita, tanto em línguas adicionais, quanto em primeiras línguas (GERALDI, 1995; 2006; DOLZ; NOVERRAZ; SCHNEUWLY, 2004; BUNZEN, 2006; ELIAS; KOCH，2011; FREITAS; VARGENS, 2010; 2016). 
Este artigo se organiza em três seções, além desta primeira, introdutória: na segunda, há uma discussão sobre a educação linguística em línguas adicionais, com foco na produção escrita, e sobre o PNLD; na terceira, há uma breve descrição dos procedimentos de pesquisa; na quarta, apresenta-se a análise das atividades de escrita presentes nas coleções de espanhol aprovadas pelo PNLD 2011, 2012, 2014 e 2015; na quinta, estão as considerações finais.

\section{AS LÍNGUAS ADICIONAIS NA EDUCAÇÃO BÁSICA, A PRODUÇÃO ESCRITA E O PNLD}

As línguas adicionais na escola integram um amplo processo educativo que envolve a socialização da cultura da vida, a construção, a manutenção e a transformação de conhecimentos e de valores. Educar é uma ação política, pois articula posicionamentos e escolhas, bem como modos de compreender e de agir no mundo (BRASIL, 2013). Conforme afirma Arroyo (2012, p. 44), a educação se refere, especialmente em uma perspectiva integral, ao "direito ao conhecimento, às ciências e tecnologias com o direito às culturas, aos valores, ao universo simbólico, ao corpo e suas linguagens, expressões, ritmos, vivências, emoções, memórias e identidades diversas".

A educação linguística, seja em primeiras línguas, seja em línguas adicionais, é parte desse amplo processo. Dessa forma, conforme sinaliza Geraldi (2006), envolve uma opção política que se expressa na seleção de metodologias, de conteúdos, de materiais, de avaliações. A questão primeira, segundo o autor (2006, p. 40) é "para que ensinamos o que ensinamos?". A resposta apontada por ele articula uma concepção de linguagem e uma visão de educação.

Geraldi (2006, p. 45) entende que a educação linguística deve priorizar o domínio das "habilidades de uso da língua em situações concretas de interação, entendendo e produzindo enunciados, percebendo as diferenças entre uma forma de expressão e outra", não o domínio de conceitos e de metalinguagens. Assim, o objetivo deve ser o de propiciar o desenvolvimento da competência discursiva dos estudantes em diferentes situações de enunciação, envolvendo práticas de linguagem orais e escritas; além disso, também é promover a autopercepção do estudante como sujeito e propiciar avanços em sua atuação na sociedade de forma consciente e crítica, lendo a palavra e lendo o mundo (FREIRE, 1989).

Para além da codificação e da decodificação, a educação linguística propicia aos estudantes um amplo leque de práticas de linguagem, compreendidas como práticas sociais contextualizadas. Nessa perspectiva, a escrita assume um papel 
relevante. Tendo ocupado lugar periférico no ensino escolar de língua espanhola ao longo do século XX (ALBUQUERQUE, 2019), tampouco tinha destaque em língua portuguesa, pois até a década de 60 resumia-se à imitação dos bons autores por meio de exercícios de composição (BUNZEN, 2006). A partir de então, começa a consolidar-se nas aulas de português a prática do gênero discursivo escolarizado redação, um pseudotexto (SOARES, 2011), posto que não circula no mundo social extraescolar. No entanto, representava algum avanço se comparada à composição, pois incentiva a "criatividade do aluno" (ROJO, CORDEIRO, 2004).

A respeito da escrita escolar, em um artigo da antológica coletânea $\mathrm{O}$ texto na sala de aula, publicado em primeira edição em 1984, João Wanderley Geraldi (2006) já abordava a distinção entre "redação" e "produção textual", entendendo a segunda como uma consistente mudança de atitude no âmbito educativo. Na tradicional metodologia que preserva a "redação", a escrita não estimula o engajamento discursivo do estudante em função de sua condição de pseudotexto (SOARES, 2011), desvinculado do mundo extraescolar e das práticas sociais. Afirma Geraldi (2006, p. 128):

\begin{abstract}
$\mathrm{Na}$ escola não se produzem textos em que um sujeito diz sua palavra, mas simula-se o uso da modalidade escrita, para que o aluno se exercite no uso da escrita, preparando-se para de fato usá-la no futuro. É a velha história da preparação para a vida, encarando-se o hoje como não vida. É o exercício. [...] Ao descaracterizar o aluno como sujeito, impossibilita-se-lhe o uso da linguagem. Na redação, não há um sujeito que diz, mas um aluno que devolve ao professor a palavra que the foi dita pela escola.
\end{abstract}

Segundo o mesmo autor (GERALDI, 2006), os docentes devem tornar-se verdadeiros interlocutores dos textos produzidos pelos estudantes, respeitando sua palavra e seu mundo. Isso é inviável nos moldes da redação escolar, caracterizada pela tentativa de apagamento da subjetividade e pela busca de uma padronização artificial de estilo, tema e construção composicional.

Além disso, Geraldi (1995) apresenta uma definição de texto relevante para as reflexões aqui apresentadas, uma vez que, como poderá ser observado na quarta seção deste artigo, há coleções didáticas que entendem como produção textual qualquer uso da língua escrita, inclusive em exercícios de pergunta-resposta. Afirma o autor que texto é

[...] uma sequência verbal escrita coerente formando um todo acabado, definitivo e publicado: onde publicado não quer dizer "lançado por uma editora", mas simplesmente dado a público, isto é, cumprindo sua finalidade de ser lido, o que demanda o outro [...] (GERALDI, 1995, p.100). 
Em perspectiva semelhante, Antunes também entende que a produção escrita na escola deve ir além do gênero escolarizado "redação":

\begin{abstract}
As propostas para que os alunos escrevam textos devem corresponder aos diferentes usos sociais da escrita - ou seja, devem corresponder àquilo que, na verdade, se escreve fora da escola - e assim, sejam textos de gêneros que têm uma função social determinada, conforme as práticas vigentes na sociedade. A famosa "redação" - que aparece sempre como um texto de caráter dissertativo - parece ter assumido a condição de gênero escolar único, pois pouca coisa diferente se escreve na escola, sobretudo nas séries do Ensino Médio. Não admira, pois, que mais tarde, escrever qualquer outro gênero de texto se torne uma tarefa praticamente inviável. (ANTUNES, 2003, p. 62-63)
\end{abstract}

A prática repetitiva de um gênero que está presente somente na escola e em exames, que é padronizado e muito estável, pouco passível a transgressões, não pode permitir um efetivo avanço da competência escrita dos estudantes, conforme ressalta Antunes (2003).

A escola precisa incorporar práticas discursivas do mundo social. Na vida humana convive-se com uma diversidade muito ampla de textos com estilos, temas e construções composicionais que, articulados, compõem os "tipos relativamente estáveis de enunciados", ou seja, os gêneros discursivos (BAKHTIN, 2003, p. 262). Tal conceito construído pelo Círculo de Bakhtin (BAKHTIN, 2003; VOLÓCHINOV, 2017), inexoravelmente relaciona a língua aos campos da atividade humana e à sociedade. Ao permitir o acesso de estudantes a textos de gêneros diversos, pertencentes a contextos públicos, expande-se a possibilidade de sua atuação no mundo por meio de práticas discursivas na língua estudada, seja primeira língua, seja língua adicional.

Estilo, tema e construção composicional são elementos indissociáveis e conformadores dos gêneros discursivos. Essa última diz respeito à organização dos elementos do gênero, ao seu acabamento e à relação dialógica entre os seus interlocutores. O conteúdo temático é o sentido do enunciado completo, o limite superior da significação linguística (VOLÓCHINOV, 2017). Já o estilo se relaciona com a "seleção dos recursos lexicais, fraseológicos e gramaticais da língua" (BAKHTIN, 2003, p. 261) utilizados na composição do gênero.

O trabalho educativo com a produção textual, a partir de perspectivas discursivas ou textuais (DOLZ; NOVERRAZ; SCHNEUWLY, 2004; GERALDI, 1995; 2006; ELIAS; KOCH, 2011; FREITAS; VARGENS, 2016), tem como característica a realização de atividades prévias e posteriores ao ato da escrita, entendido como um processo. Além disso, pressupõe uma concepção de estudante como um sujeito que assume suas palavras e suas ações para ser capaz de confrontar suas experiências de vida e seu saber acumulado, conforme defende Geraldi (2006). 
Se tomado o gênero discursivo como eixo do processo de educação linguística, as atividades prévias e posteriores deveriam, portanto, relacionar-se não somente ao estilo, ao tema e à construção composicional, mas também ao campo de atividade envolvido e à função social do texto (FREITAS; VARGENS, 2010; 2016).

De acordo com Elias e Koch (2009), a escrita e seu ensino são perpassados por três concepções teóricas distintas. A primeira tem a língua como foco e entende a escrita como uma codificação realizada por um autor. A segunda concepção tem o escritor como foco e, portanto, o texto é entendido como a representação do pensamento e das intenções do autor. Nessas duas visões, o sentido é considerado imanente e, como tal, fixo e inegociável, pois a língua seria transparente e ahistórica. $\mathrm{Na}$ terceira concepção, o texto é o meio para uma interação dialógica entre escritor e leitor, ambos sujeitos ativos que se constroem e se constituem no texto. Essa perspectiva permite a elaboração de atividades de escrita incorporando gêneros discursivos que circulam no mundo social extraescolar, por meio dos quais o estudante diz a sua palavra e tem interlocutores para além do próprio docente, que também se torna um leitor-interlocutor, não apenas um corretor do texto do estudante.

Elias e Koch (2009) levantam, ainda, uma série de estratégias que envolvem a atividade didática de produção de textos escritos: ativação de conhecimentos sobre a situação de enunciação seleção, organização e desenvolvimento das ideias, de modo a garantir a continuidade e a progressão temática; equilíbrio entre informações explícitas e implícitas, "novas" e "dadas"; revisão contínua do texto ao longo do processo.

Além dessas estratégias, a refacção após uma primeira leitura do professor é mencionada por diversos autores (DOLZ; NOVERRAZ; SCHNEUWLY, 2004; FREITAS; VARGENS, 2016; MARCUSCHI, 2010) como elemento importante para o avanço na competência escrita.

Para investigar a produção escrita, esta pesquisa optou por analisar coleções didáticas aprovadas pelo PNLD, tendo em vista o impacto na educação das obras aprovadas nesse programa, que é uma política pública de distribuição de livros didáticos, obras literárias, obras complementares e dicionários às escolas brasileiras. As proporções do PNLD, que é o maior programa dessa natureza no mundo, são gigantescas: alcança mais de 99\% das instituições escolares públicas do país (FNDE, 2019), conta com o quarto maior orçamento da união e converteu o governo brasileiro no maior comprador de livros do país (CASSIANO, 2007).

Abaixo, uma tabela com os dados numéricos da distribuição de obras pelo PNLD, dos editais de 2014 a 2019: 
Tabela 1. Dados dos PNLDs (2014 a 2019)

\begin{tabular}{|c|c|c|c|c|}
\hline Edital & $\begin{array}{c}\text { Escolas } \\
\text { Beneficiadas }\end{array}$ & $\begin{array}{c}\text { Alunos } \\
\text { Beneficiados }\end{array}$ & Exemplares & Valores (R\$) \\
\hline PNLD 2019 & 147.857 & 35.177 .899 & 126.099 .033 & $1.102 .025 .652,17$ \\
\hline PNLD 2018 & 117.566 & 31.137 .679 & 153.899 .147 & $1.467 .232 .112,09$ \\
\hline PNLD 2017 & 117.690 & 29.416 .511 & 152.351 .763 & $1.295 .910 .769,73$ \\
\hline PNLD 2016 & 121.574 & 34.513 .075 & 128.588 .730 & $1.070 .680 .044,28$ \\
\hline PNLD 2015 & 123.947 & 30.601 .344 & 144.291 .373 & $1.175 .967 .978,38$ \\
\hline PNLD 2014 & 121.279 & 39.403 .259 & 157.134 .808 & $1.217 .893 .067,42$ \\
\hline
\end{tabular}

Embora haja registro de políticas públicas relativas ao livro e, especificamente, ao livro didático, ao longo de quase todo o século XX (FREITAS; DAHER; SANT'ANNA, 2013), o PNLD começou em 1985 (BRASIL, 1985). Um importante passo do Programa se deu em 1996, quando começou a chamada Fase II. A partir de então, estabeleceu-se a avaliação pedagógica das obras didáticas, a partir de critérios estabelecidos em edital que, de 2002 a 2018, foi realizada por universidades públicas em convênio com o Ministério da Educação. Ao longo dos anos, gradativamente o Programa foi incorporando os componentes curriculares e, hoje, todas as disciplinas obrigatórias em âmbito federal são contempladas.

Outro episódio relevante foi a promulgação do Decreto $n^{0} 7.084 / 2010$, que manteve as características do Programa e seus avanços ao longo dos anos, como o atendimento exclusivo de escolas públicas e a avaliação das obras realizada por universidades públicas. Em 2017, em um momento político brasileiro muito diferente do anterior, após o impeachment da Presidenta Dilma Rousseff, a publicação Decreto 9.099 (BRASIL, 2017b) marca o início de uma Fase III do PNLD, conforme demarca Silvério (2019). Algumas mudanças significativas são as seguintes: atender, além de escolas públicas, instituições comunitárias, confessionais ou filantrópicas sem fins lucrativos; permitir a distribuição de materiais apostilados; submeter os critérios específicos dos editais à Base Nacional Comum Curricular (BNCC); retirar das universidades o processo de avaliação das obras e atribui-la a uma Comissão Técnica indicada por instituições diversas, incluindo fundações privadas. Embora os livros didáticos analisados neste artigo pertençam à Fase II do PNLD, a menção à Fase III é relevante para uma compreensão histórica do Programa e das políticas públicas educativas brasileiras do século XXI. 
O componente curricular Língua Estrangeira (espanhol e inglês) foi incluído no Edital do PNLD 2011 para o Ensino Fundamental e, para o Ensino Médio, no PNLD 2012. Houve um total de seis processos de avaliação do componente: três relativos aos Anos Finais do Ensino Fundamental (2011, 2014 e 2017) e três para o Ensino Médio $(2012,2015,2018)$. Com a publicação da Medida Provisória 746/2016 (BRASIL, 2016), convertida na Lei 13.415/2017 (BRASIL, 2017a), que altera a Lei de Diretrizes e Bases da Educação Nacional, Língua Estrangeira - com a língua escolhida pela comunidade escolar - deixou de ser um componente curricular obrigatório na Educação Básica brasileira e a Língua Inglesa foi imposta em seu lugar. Ressalte-se que em toda a história do Brasil independente, pela primeira vez uma única língua adicional é obrigatória nas escolas. Assim sendo, o Edital do PNLD 2020 (MEC/FNDE/SEB, 2018) contemplou somente a Língua Inglesa.

A entrada de Língua Estrangeira nos editais do PNLD promoveu uma substancial ampliação de pesquisas sobre livros didáticos de espanhol (FREITAS,

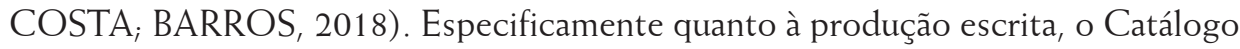
de Teses e Dissertações da CAPES (2019) apresenta como resultado somente as dissertações de Campos (2016) e de Teixeira (2016). Há, ainda, o artigo de Carneiro, Costa e Fernandes (2015), além das produções de Freitas e Vargens (2010, 2016) e de Albuquerque (2019).

O índice de aprovação de coleções de espanhol é muito baixo. Se considerados os quatro editais analisados neste texto, foram apenas nove coleções aprovadas. Níveis tão altos de exclusão de coleções de espanhol, fato que também ocorre com as obras de inglês, podem significar que a qualidade dos livros didáticos deixa muito a desejar e, que, portanto, pesquisas enfocando tais materiais são relevantes e necessárias.

Nos critérios eliminatórios da área de Língua Estrangeira dos quatro Editais do PNLD que estão em questão neste artigo (2011, 2012, 2014 e 2015) ${ }^{1}$, há elementos que vão ao encontro da perspectiva da escrita como processo e como interação, conforme visto neste artigo.

Observando mais detalhadamente os critérios específicos da área de Língua Estrangeira nos editais, é possível notar aproximações com relação à concepção de escrita como processo interativo. O edital do PNLD 2011 apresenta um maior detalhamento nos critérios específicos (VÁZQUEZ; FREITAS, 2017), inclusive sobre a produção escrita, enquanto que os editais seguintes são muito semelhantes

1. A avaliação dos processos de Língua Estrangeira Moderna foi realizada pela Universidade Federal de Minas Gerais, no PNLD 2011, e pela Universidade Federal Fluminense no PNLD 2012, 2014 e 2015. 
entre si, com mudanças pontuais, como a substituição de "gêneros de texto" (PNLD 2012) por "gêneros de discurso" (PNLD 2014 e 2015), o que já pode implicar uma mudança teórico-metodológica significativa, conforme aponta Rojo (2005).

Os critérios específicos relativos à escrita presentes no Edital do PNLD 2011 (MEC/FNDE/SEB, 2008, p. 58) são os seguintes:

- tratar a produção escrita como processo interativo e em constante reformulação;

- considerar o uso social da escrita e trabalhar, de forma contextualizada e, tanto quanto possível, com finalidades precisas, com diferentes gêneros e tipos textuais;

- apresentar e discutir as características sócio-discursivas dos gêneros abordados, levando em conta as condições de produção e o potencial receptor do texto;

- explicitar as condições de produção: quem escreve e como se projeta enquanto enunciador, para quem escreve e como projeta o seu leitor, com que objetivo, em que suporte e em que momento;

- refletir sobre as regras e convenções que regem determinado sistema linguístico no âmbito de recursos ortográficos, morfológicos, semânticos, sintáticos, estilísticos, retóricos e discursivos;

- contemplar e refletir sobre as diferentes etapas do processo de produção.

Já no Edital do PNLD 2012 (MEC/FNDE/SEB, 2009, p. 24), há apenas um item envolvendo a escrita:

- propõe atividades de produção escrita como processo de interação, que exige a definição de parâmetros comunicativos, bem como o entendimento de que a escrita se pauta em convenções relacionadas a contextos e gêneros de texto, e deve estar submetida a constante processo de reelaboração.

O mesmo ocorre no Edital do PNLD 2014 (MEC/FNDE/SEB, 2011, p. 67):

- promove atividades de produção escrita compreendida como processo de interação, que exige a definição de parâmetros comunicativos, o entendimento de que a escrita se pauta em convenções relacionadas a contextos e gêneros de discurso e está submetida a processo de reelaboração.

E também no Edital do PNLD 2015 (MEC/FNDE/SEB, 2013, p. 47):

- promove atividades de produção escrita, que a consideram como como processo de interação, que exige a definição de parâmetros comunicativos (quem, para quem, com que objetivos), o entendimento de que a escrita se pauta em 
convenções relacionadas a contextos e gêneros de discurso e está submetida a processo de reescrita do próprio texto.

Assim sendo, os editais exigem que a escrita esteja presente nas coleções aprovadas como um processo sócio-interativo, organizado em etapas que incluem a refacção, com parâmetros comunicativos definidos e que se manifeste por meio de um gênero, em um contexto definido.

\section{PROCEDIMENTOS DE PESQUISA}

A fim de iniciar o contato com as coleções, primeiramente foram observados os Manuais do Professor (MP), inclusive para definir o recorte do material para análise. Considerando as dimensões encontradas, com grande quantidade de propostas de escrita, optou-se por analisar as atividades do último volume de cada obra, ou seja, os livros destinados ao $9^{\circ}$ ano do Ensino Fundamental e ao $3^{\circ}$ ano do Ensino Médio. O motivo da escolha se deve à inferência de que, ao se tratar do último volume, destinado a estudantes que passaram os dois ou três anos anteriores estudando espanhol, as atividades poderiam ser mais complexas e apresentar um trabalho mais significativo na perspectiva da escrita como processo.

Após a análise dos $\mathrm{MPs}_{\mathrm{s}}$, foram realizados os primeiros registros a respeito da perspectiva teórico-metodológica de produção escrita que as coleções explicitam. Com isso, posteriormente, foi possível observar se havia coerência entre a proposta defendida no MP e o que se efetivava no Livro do Estudante (LE). O passo seguinte foi a elaboração de um roteiro para análise das atividades. O instrumento, reproduzido a seguir, possui onze itens, um deles com três subitens, todos pensados a partir da perspectiva da escrita como processo, conforme se argumenta ao longo deste artigo e se exige nos editais do PNLD. 


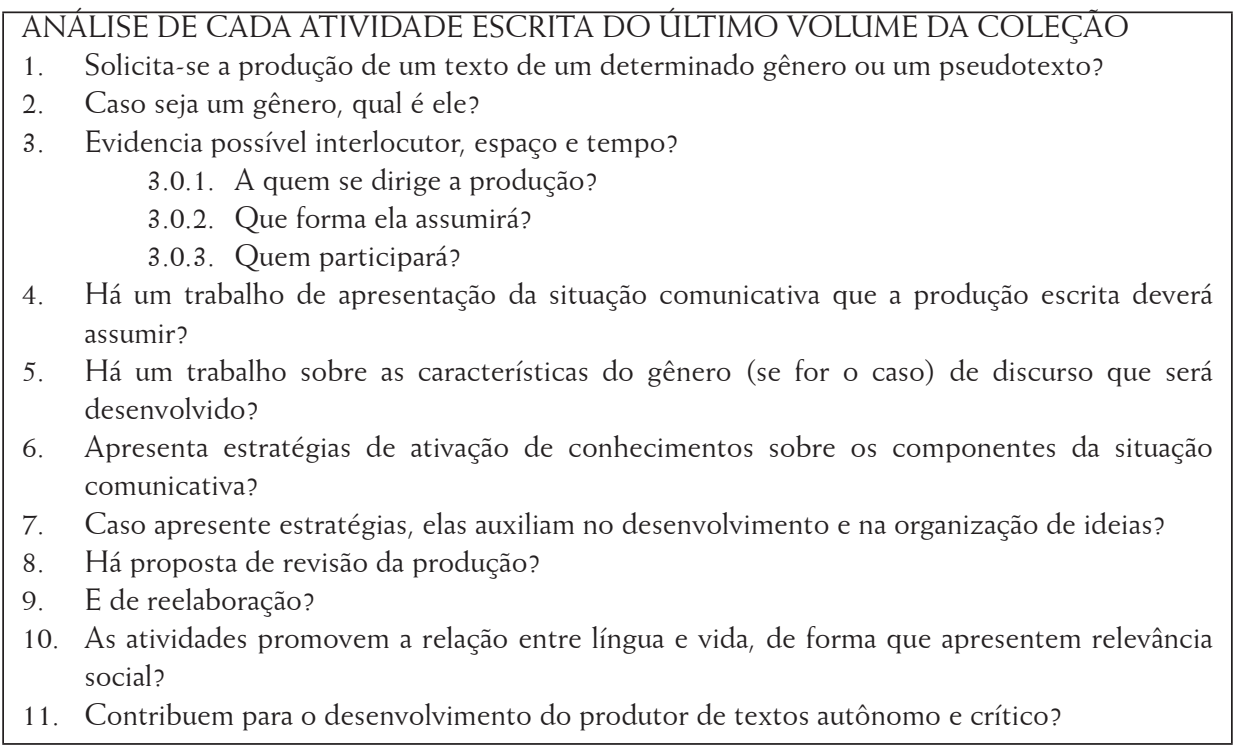

No que tange à organização geral das coleções, todas dispõem de dois volumes, um LE e um MP, para cada ano escolar. Todos os MPs reproduzem os LEs, acrescidos das respostas das atividades e de eventuais comentários dirigidos aos professores, além de dispor de um adendo com o suporte teórico-metodológico da coleção, orientações específicas para cada unidade e atividades complementares. Esse suporte costuma receber também o nome de Manual do Professor e, em geral, encontra-se ao final do volume.

\section{A ESCRITA NAS COLEÇÕES DE ESPANHOL APROVADAS PELO PNLD}

Nesta seção, apresenta-se a análise das atividades escritas das coleções aprovadas no PNLD 2011, 2012, 2014 e 2015, organizadas em ordem cronológica para observar possíveis avanços ocorridos nesta breve série histórica de editais.

Tendo em vista a natureza deste artigo, é imprescindível que as análises venham acompanhadas de uma descrição do encontrado em cada coleção, bem como de imagens de atividades que representariam um padrão das propostas presentes nas obras. 


\subsection{PNLD 2011}

No edital do PNLD 2011, destinado aos anos finais do Ensino Fundamental, foram aprovadas apenas duas coleções de língua espanhola: Saludos - curso de lengua española (MARTIN, 2009) e Español: ientérate! (BRUNO; ARRUDA; TONI, 2009). Ambas já estavam disponíveis no mercado privado anteriormente, ou seja, não foram elaboradas especificamente para atender ao edital do PNLD. Segundo o Guia de Livros Didáticos do PNLD 2011 (MEC/SEB, 2010, p.18), o desempenho na produção escrita de Saludos - curso de lengua española (MARTIN, 2009) foi bom, enquanto que Español: ientérate! (BRUNO; ARRUDA; TONI, 2009) teve por resultado muito bom.

A coleção Saludos - curso de lengua española é de autoria de Ivan Martin (2009). Os volumes se dividem em oito unidades, quatro suplementos (Proyecto) e quatro revisões (Repaso). Todas as unidades possuem uma seção exclusiva para as atividades de produção escrita, que é denominada Así lo dices; no entanto, nas unidades 2, 5, 6 e 8 , não há uma efetiva atividade de escrita na seção; em contrapartida, nos Proyectos 2, 3 e 4 há propostas de elaboração de textos escritos.

$\mathrm{O}$ adendo do MP destinado especificamente ao professor contém uma seção para o tratamento da escrita (Compreensão e produção escrita), que defende a ideia de processo. A coleção afirma que o professor deve constituir estratégias para a pré-escrita, a escrita e a revisão do texto que, por sua vez, seriam as três fases constituintes da produção textual. O MP também defende a necessidade de definição da situação de produção: quem escreve, com que finalidade e para quem. Dessa forma, sustenta que as atividades da coleção estariam atentas a uma visão discursiva escrita, coincidindo com o previsto no edital do PNLD 2011 e com as concepções presentes em grande parte das referências atualizadas sobre o tema, mencionadas na seção 2 deste artigo, com uma aproximação à visão de escrita com foco na interação (ELIAS, $\mathrm{KOCH}$, 2009). Afirma, assim, que as propostas da obra ampliariam os espaços para o desenvolvimento da competência linguística do estudante e também do seu olhar crítico e reflexivo.

Segundo consta no MP, a seção Así lo dices seria composta por atividades de dois tipos: em algumas, os estudantes deveriam responder a perguntas diretas com frases curtas; em outras, deveriam criar pequenos textos para falar de si mesmos. No entanto, na definição de Geraldi (1995), somente o segundo tipo seria uma efetiva atividade de produção escrita, uma vez que responder a perguntas não se constitui como a construção de um texto. Sendo assim, foram analisadas na pesquisa somente as propostas do segundo tipo. O MP ainda apresenta sugestões de como proceder nas atividades, como a elaboração de um roteiro para a produção escrita 
que consistiria em: planejamento do texto; seleção das informações, redação do rascunho, consulta a dicionários, pré-correção do rascunho; redação final do texto.

Ao analisar as atividades presentes no LE, observou-se que há textos que servem como base para as atividades que virão a ser desenvolvidas. Entretanto, apesar de a situação comunicativa estar sempre relativamente evidenciada, o suporte e a fonte não aparecem, com exceção da Unidad 8, cuja fonte aparece indicada. A falta dessas informações faz supor que são elaborados para fins didáticos. Dessa forma, por não serem textos que circulam, efetivamente, no mundo social, as atividades de produção se distanciam de práticas sociais contextualizadas e se aproximam de produções de pseudotextos (SOARES, 2011), ou seja, são exercícios, no sentido atribuído por Geraldi (2006). Além disso, é importante relembrar que em quatro unidades não há efetiva proposta de escrita, apenas exercícios de pergunta-resposta.

As atividades de produção textual encontradas no suplemento Proyecto demostraram-se mais próximas à visão de escrita como processo e interação (ELIAS, $\mathrm{KOCH}, 2009)$, conforme se defende neste artigo. Como os textos propostos aos estudantes sempre pertencem a um determinado gênero do mundo social extraescolar, há maior nitidez quanto aos objetivos da produção em relação à situação comunicativa. Dessa forma, as atividades podem ser capazes de promover uma relação entre língua e vida, como pressupõe a concepção dialógica de linguagem (BAKHTIN, 2003; VOLÓCHINOV, 2017), apresentando maior relevância social e contribuindo para o desenvolvimento de um produtor de textos autônomo e crítico (GERALDI, 2006). Cabe ressaltar, entretanto, que há apenas três propostas com tal configuração, nos Proyectos 2, 3 e 4; ou seja, de um total de doze atividades de escrita, somente um quarto se produz a partir de tais pressupostos. Além disso, a perspectiva de gênero que se antevê é a textual, não a discursiva (ROJO, 2005).

No que se refere às atividades da seção Así lo dices, constatou-se que em muitas unidades não há uma efetiva proposta de elaboração textual e, quando há, o que se solicita é um pseudotexto (SOARES, 2011). Os comandos das atividades não evidenciam possíveis interlocutores, espaço e tempo para a produção. De maneira geral, ou não apresentam estratégias de ativação de conhecimentos sobre os componentes da situação comunicativa, ou as apresentam de maneira insatisfatória e pouco eficiente, como pode ser verificado no seguinte exemplo: 


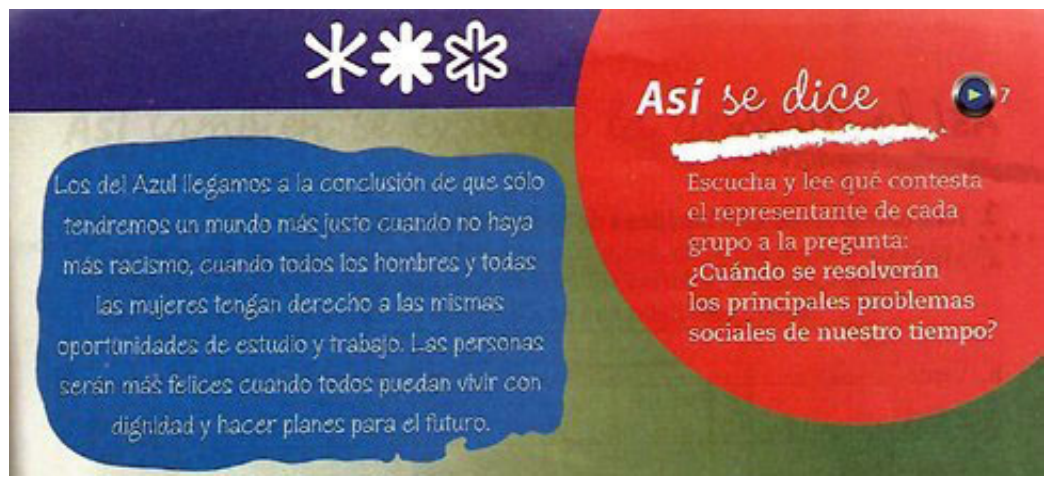

Imagem 1. Seção Así se dice (Capítulo 3), com a pergunta usada na produção escrita Fonte: Martin (2009, p. 41)

\section{Y tú, ¿cómo contestarías a la pregunta? Forma un grupo con tus compañeros -... y discute el problema. Después escribe un texto como los que has leído.}

Imagem 2. Seção Así lo dices (Capítulo 3)

Fonte: Martin (2009, p. 42)

Conclui-se, portanto, que tais atividades se reduzem a uma redação, gênero escolarizado questionado intensamente nas últimas três décadas (GERALDI, 2006; ANTUNES, 2003), que não atende às práticas sociais situadas, e demonstram uma visão de escrita com foco na língua (ELIAS, $\mathrm{KOCH}, 2009)$. As propostas pedem a elaboração de textos sobre um determinado tema, sem explicitação de um gênero extraescolar e sem objetivos definidos, aproximando-se, inclusive, da composição presente em obras didáticas dos anos 1940 (ALBUQUERQUE, 2019). Diante disso, são diversos os fatores que fazem com que tais propostas não promovam a relevância social da escrita e não contribuam para o desenvolvimento de um produtor de textos autônomo e crítico.

É importante ressaltar que nenhuma das atividades pede revisão e reelaboração da produção do aluno, demonstrando, assim, que a preocupação é com o produto final em forma de exercício (GERALDI, 2006), não com o processo interativo de ensino-aprendizagem, entrando em conflito com o que o MP defende. Igualmente, o procedimento processual mencionado no adendo dirigido ao professor não é encontrado nas propostas do LE. 
A coleção Español: ientérate! é de autoria de Fátima Aparecida Cabral Bruno, Silvia Aparecida Ferrari de Arruda e Margareth Aparecida Martinez Benassi Toni (2009). Os volumes possuem oito unidades e, ao final, três apêndices.

No adendo específico para o professor do MP, o tratamento da escrita está em uma subseção exclusiva denominada Expresión escrita. Afirma-se que as atividades contariam com diferentes momentos, encaminhando o estudante quanto à elaboração de orações e de textos de diversos graus de complexidade. Assim sendo, entende que uma oração seria uma produção escrita, algo que não constitui um todo acabado e, portanto, não configuraria um texto. Além disso, o MP aponta que caberia ao docente orientar os estudantes sobre o fato de que a escrita envolveria planejamento, produção e revisão, aproximando-se do prescrito no edital do PNLD 2012 e de concepções atualizadas sobre a escrita como processo interativo (ELIAS, $\mathrm{KOCH}, 2009)$.

O LE apresenta quantidade significativa de atividades de escrita, pois cada unidade possui uma média de cinco questões identificadas pela coleção como sendo de escrita. No entanto, a maioria das propostas não é de produção textual, mas de leitura ou de gramática. Há questões, por exemplo, de múltipla escola, de sopa de letras e de sublinhar a sílaba tônica indicadas como sendo de escrita por um ícone específico ("Escribir"). Isso demonstra um entendimento equivocado do que seria a elaboração de textos, confundindo-a com o ato de usar a língua escrita.

Há, ainda, muitas questões de leitura identificadas como de escrita. Dentre elas, atividades que exigem somente identificação e cópia, aproximando-se de uma (de)codificação que, por sua vez, não colabora com a formação de um leitor e de um produtor de textos autônomo e crítico, conforme seria o esperado como direito linguístico no processo educativo (ARROYO, 2012). Igualmente, questões de ordem gramatical foram encontradas sob o ícone "Escribir", inclusive uma tabela de conjugação verbal, questões de completar lacunas com itens gramaticais, exercícios de reformulação de frases soltas, produção de textos como pretexto para o trabalho de determinado item gramatical, como, por exemplo, reescrita de um texto usando discurso indireto.

É possível perceber que a maioria das atividades não é, portanto, de escrita. Dessa forma, não foram analisadas nesta pesquisa, uma vez que são de outras ordens. Tendo em vista esse fato, foram observadas dezessete questões que efetivamente exigiriam a elaboração de um texto do aluno. Dentre estas, constatou-se que sete solicitam a produção de pseudotextos (SOARES, 2011), ou seja, textos que não pertencem a um gênero que circula no mundo social extraescolar, conforme a que se reproduz a seguir, da Unidad 6. 


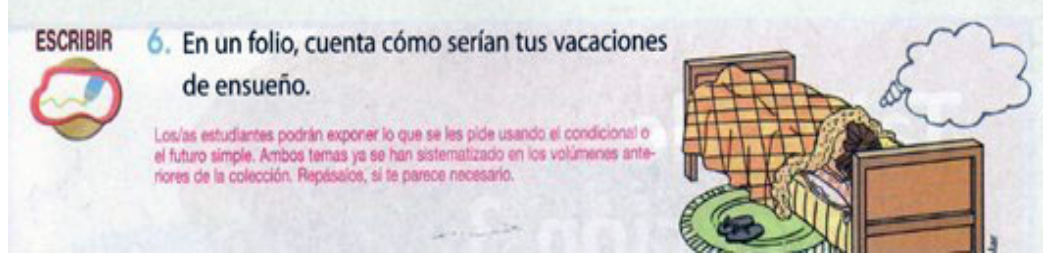

Imagem 3. Seção Escribir (Unidad 6)

Fonte: Bruno, Arruda e Toni (2009, p. 93).

Há, ainda, uma oitava atividade demandando a escrita de um gênero que é da modalidade oral. Das dezessete atividades, apenas duas explicitam um possível interlocutor e a forma que o texto produzido deveria assumir. Dentre as nove questões que solicitam a produção de textos de um determinado gênero, somente quatro apresentam um quadro ("Tip") com breves informações sobre suas características e três possuem alguma referência à situação que a produção deveria assumir. Demonstram, portanto, pouca relação entre língua e vida (BAKHTIN, 2003; VOLÓCHINOV, 2017), além de pequena relevância social da escrita para o estudante (GERALDI, 2006).

É importante ressaltar, também, que nenhuma atividade de escrita do volume apresenta proposta de revisão e de reelaboração da produção, embora esses procedimentos constem no MP como parte do processo de escrita, ou seja, não há coerência entre o proposto no MP e o apresentado no LE: no primeiro, a escrita parece ter foco na interação; no segundo, foco na língua (ELIAS, KOCH, 2009).

Conclui-se, portanto, que a maioria das atividades propostas na coleção Español: ientérate! (BRUNO; ARRUDA; TONI, 2009) é artificial, ou seja, não representa uma prática de linguagem do mundo social, não explicita interlocutores e não situa a produção em um determinado espaço e tempo. Atestam, na verdade, que as atividades funcionam apenas como forma de avaliação e de exercitação de determinados elementos sistêmicos trabalhados ao longo das unidades, conforme critica Geraldi (2006).

Uma síntese das características encontradas nas atividades de produção escrita das coleções aprovadas no PNLD 2011, Saludos - curso de lengua española (MARTIN, 2009) e Español: ientérate! (BRUNO; ARRUDA; TONI, 2009) está a seguir:

- predomínio de propostas de elaboração de pseudotextos (SOARES, 2011) ou de uso da modalidade escrita da língua em respostas, orações etc.;

- falta de explicitação dos interlocutores e da finalidade da produção;

- ausência de propostas de revisão ou de reelaboração dos textos produzidos; 
- presença de atividades que, de maneira geral, são formas de avaliação e de exercitação de elementos sistêmicos;

- incoerência entre o proposto no MP, que corresponde a uma perspectiva de escrita como processo, e o apresentado no LE.

\subsection{PNLD 2012}

No edital de 2012, destinado ao Ensino Médio, foram aprovadas três coleções de língua espanhola: Síntesis - curso de lengua española (MARTIN, 2010), Enlaces: español para jóvenes brasileños (OSMAN et al, 2010) e El arte de leer español (PICANÇO; VILLALBA, 2010). Todas já estavam disponíveis no mercado privado anteriormente e não foram elaboradas especificamente para atender ao edital.

Segundo o Guia de Livros Didáticos do PNLD 2012 (MEC/SEB, 2011, p.11), todas as três coleções tiveram um desempenho muito bom na produção escrita.

A coleção Sintesis - curso de lengua española é de Ivan Martin, mesmo autor de Saludos - curso de lengua española (MARTIN, 2009), obra para o Ensino Fundamental aprovada pelo PNLD 2011. Os livros possuem oito unidades, suplementos (Apartado 1 e 2) localizados após as unidades 4 e 8 e dois apêndices ao final.

No MP, a parte específica para leitura do professor apresenta a produção escrita como parte de uma seção das unidades denominada Para charlar y escribir. Conforme sugere o título, o adendo defende a inserção de exercícios de conversação no momento inicial da atividade de produção uma vez que eles seriam ampliados e se transformariam em estímulo para a escrita.

Nessa seção do MP, citam-se alguns gêneros como exemplos do trabalho com a produção; no entanto, analisando o LE, observa-se que cinco de um total de oito propostas presentes em Para charlar y escribir solicitam a elaboração de pseudotextos (SOARES, 2011). Em seis unidades, não são indicados os interlocutores da produção e o papel que o estudante deverá assumir na produção.

Em três unidades, há proposta de escrita indicando gêneros discursivos específicos - receita, história em quadrinhos e lenda -, mas não há um trabalho consistente de apresentação de suas características estilísticas, composicionais e temáticas. Além disso, têm o papel de ser apenas pretexto para a fixação de determinado elemento gramatical, algo contestado de forma enfática há mais de três décadas (LAJOLO, 1982). Por exemplo, no Capítulo 4 (p.68), a produção de um texto do gênero receita gira em torno da utilização de verbos no modo imperativo, no Capítulo 2, uma atividade de escrita de um pseudotexto (SOARES, 2011) com planos para o futuro, cujo evidente objetivo é a prática de verbos no subjuntivo. Esta última é reproduzida a seguir. 

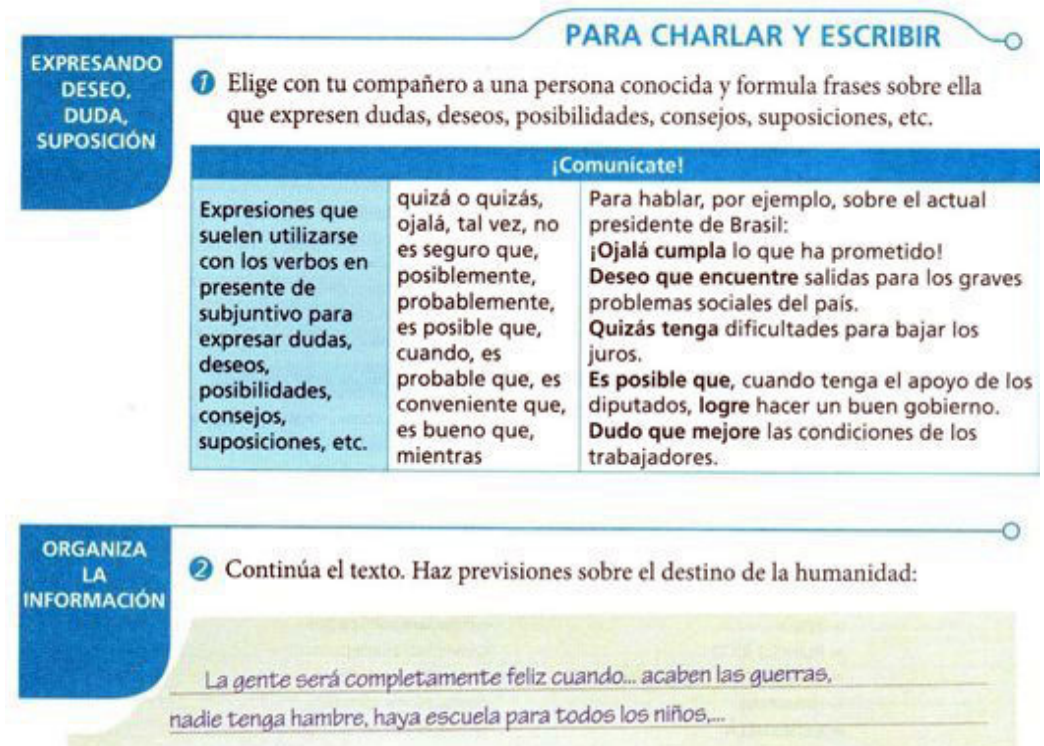

Imagem 4. Seção Para charlar y escribir (Capítulo 2)

Fonte: Martin (2010, p. 36)

No Capítulo 8, é pedida a elaboração de um texto do gênero lenda (p.148). Nesse caso, percebe-se um completo apagamento do sujeito escritor/produtor de textos, conforme critica Geraldi (2006). A proposta já apresenta os personagens, o enredo, o lugar e o tempo. Além disso, traz os verbos de cambio que podem ser utilizados. Só resta ao estudante unir os dados. Dessa forma, não há um trabalho para o desenvolvimento da autonomia no processo da escrita, concebida com foco na língua (ELIAS, $\mathrm{KOCH}, 2009)$.

Aprovada no mesmo edital, a coleção Enlaces: español para jóvenes brasileños é de autoria de Soraia Osman, Neide Elias, Priscila Reis, Sonia Izquierdo e Jenny Valverde. Seus volumes são divididos em oito unidades e cinco apêndices. A seção dedicada à escrita é denominada En otras palabras.

O tratamento teórico-metodológico da escrita aparece no MP na seção ¿Cómo es la estructura de la unidad?, em um breve parágrafo que tem o mesmo nome presente no LE: En otras palabras. Percebe-se uma visão de escrita com foco na interação (ELIAS, $\mathrm{KOCH}, 2009)$, pois se afirma que as atividades de produção têm como objetivo sistematizar a habilidade de reconhecer ou de identificar a configuração de diferentes gêneros discursivos escritos. Dá importância ao modo como se apresentam os gêneros e sua organização interna, sintaxe, léxico, dentre 
outros elementos. Segundo o MP, a atividade escrita da coleção também envolve a leitura, pois antes da planificação da escrita, há um texto servindo de exemplo para ser lido, com análise das suas características.

A seção En otras palabras aparece uma vez em cada unidade do LE, contendo propostas de produção que envolvem gêneros discursivos do mundo social extraescolar. As atividades apresentam exemplos dos gêneros a serem trabalhados; no entanto, três aparentam ter sido criadas para fins didáticos, pois não indicam fontes; outras quatro indicam fonte "adaptada" e apenas uma parece ser um texto não modificado. Apesar de haver em todas as atividades uma síntese, assinalada pelo ícone Análisis de género, não vai além de breves explicações quanto ao estilo e à construção composicional. A reflexão sobre a relação do gênero com o contexto de produção e de recepção, com sua função social e com o campo da atividade humana, não é explorada. Além disso, é importante ressaltar a presença de somente uma proposta de revisão no volume e a ausência total de indicações para reelaboração textual nas oito unidades. Como visto na seção 2, a revisão e reelaboração são defendidas em grande parte da produção acadêmica recente sobre a escrita.

No que se refere à apresentação da situação que a produção deveria assumir, todas as atividades se limitam ao conteúdo e a alguns elementos da construção composicional do gênero. Os possíveis interlocutores e a finalidade das produções não são mencionados, o que dificulta a compreensão e a solução do problema de comunicação proposto. Apenas na Unidad 2, indicam-se como interlocutores os colegas de classe. Percebe-se, portanto, que a perspectiva de gênero adotada é textual, não discursiva (ROJO, 2005)

Além disso, somente em cinco unidades há estratégias, embora insuficientes, de ativação de conhecimentos sobre a situação comunicativa. Assim, a produção do estudante pode acabar reduzindo-se a uma possível reprodução do exemplo que lhe é apresentado. Dessa forma, apesar de apresentar avanços significativos com relação às demais coleções observadas até este momento, Enlaces ainda não permite uma participação ativa do aluno nas atividades e a produção ainda é distante de contextos sociais de uso do gênero discursivo selecionado.

Uma atividade de escrita da coleção pode ser observada a seguir. 


\section{En otras palabras}

1. Noticia. El objeto o tema de la noticia debe referirse un acontecimiento que sea actual, todavia no conocido y presentado como verídico. La entrada de la noticia debe aclarar el acontecimiento con datos de la forma más imparcial y sintética posible, y responder a las interrogantes quién (los protagonistas), qué (el acontecimiento), cuándo (ubica la acción en un tiempo definido). dónde (informa el espacio) y cómo (describe las circunstancias en que se produjo el hecho). Su estilo debe ser claro, conciso y concreto. Lee la noticia y contesta las interrogantes anteriores.

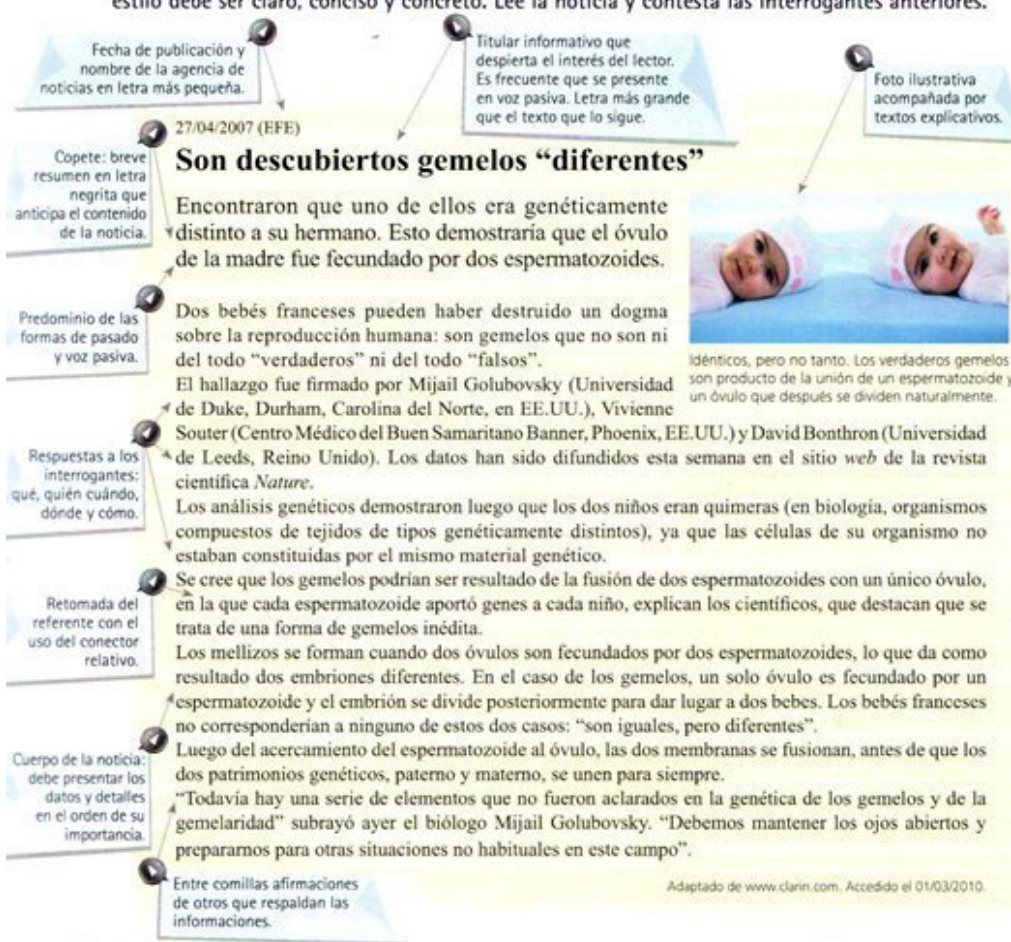

2. Escribe una noticia sobre algún descubrimiento (reciente o pasado) de la medicina o de otra ciencia, que te parezca relevante y que despierte el interés del público. Para redactarla:

- establece los acontecimientos y datos esenciales como: quièn, qué, cuảndo, dónde, cómo y cuándo:

- haz un primer esquema con los datos, teniendo en cuenta las caracteristicas del modelo anterior:

- elabora un titular que atrape al lector.

Imagem 5. Seção En otras palabras (Unidad 5)

Fonte: Osman et al (2010, p. 89)

A terceira coleção aprovada no PNLD 2012, El arte de leer español, é de autoria de Deise Cristina de Lima Picanço e Terumi Koto Bonnet Villalba. Os volumes são divididos em quatro unidades e não há uma seção exclusivamente dedicada à escrita.

$\mathrm{O}$ adendo do MP destinado à leitura do professor aborda a escrita junto com a produção oral e a compreensão auditiva. Na verdade, a coleção assume que o seu objetivo não é a escrita. Afirma que a produção textual não se separa das práticas de leitura e, por isso, algumas pequenas atividades de escrita aparecem na seção 
¿Dale!. Reforça a importância da contextualização das produções, mesmo quando são breves e integradas à leitura.

Ao analisar o LE, foram encontradas propostas de produção textual também em outras seções. É importante ressaltar que, tendo em vista a falta de indicação explícita da coleção sobre quais seriam as atividades de escrita, foi necessário utilizar outro critério, o que diferenciou o exame de El arte de leer das demais obras, nas quais foram analisadas apenas aquelas indicadas como tal no MP. Portanto, foi usado como critério a solicitação, no comando da questão, da redação de um "texto". Assim, deparamo-nos com diversas questões envolvendo a escrita. A maioria, de fato, apareceu na seção iDale!, mas algumas foram encontradas também nas seções Abora tú e Para curiosear.

Nas atividades, de maneira geral, o que se pede são produções de gêneros que circulam no mundo social extraescolar. Em algumas atividades, há repetições do mesmo gênero. É o caso do gênero painel, que é solicitado três vezes, e a campanha que, embora com alguma diferenciação (campanha publicitária de grupo ecológico e campanha ecológica), é solicitada duas vezes. Além disso, em nenhuma atividade há um trabalho com as características composicionais, temáticas e estilísticas dos gêneros solicitados. Assim, pede-se ao estudante a produção de um texto de determinado gênero sem que ele lhe seja previamente apresentado, ou seja, há uma crença na competência espontânea do estudante para a escrita, conforme se via em livros didáticos de espanhol dos anos 40 (ALBUQUERQUE, 2019). Um exemplo pode ser observado a seguir. 


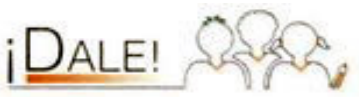

Hemos visto varias canciones y poemas hablando de amor, pero ¿qué crees que piensa la gente común sobre eso? iA ver qué escribieron algunas personas en el blog La Comunidad. de elpais.com, organizado por fgm72! Aqui el contesta a algunos comentarios sobre su texto titulado ¿Qué es la poesia?

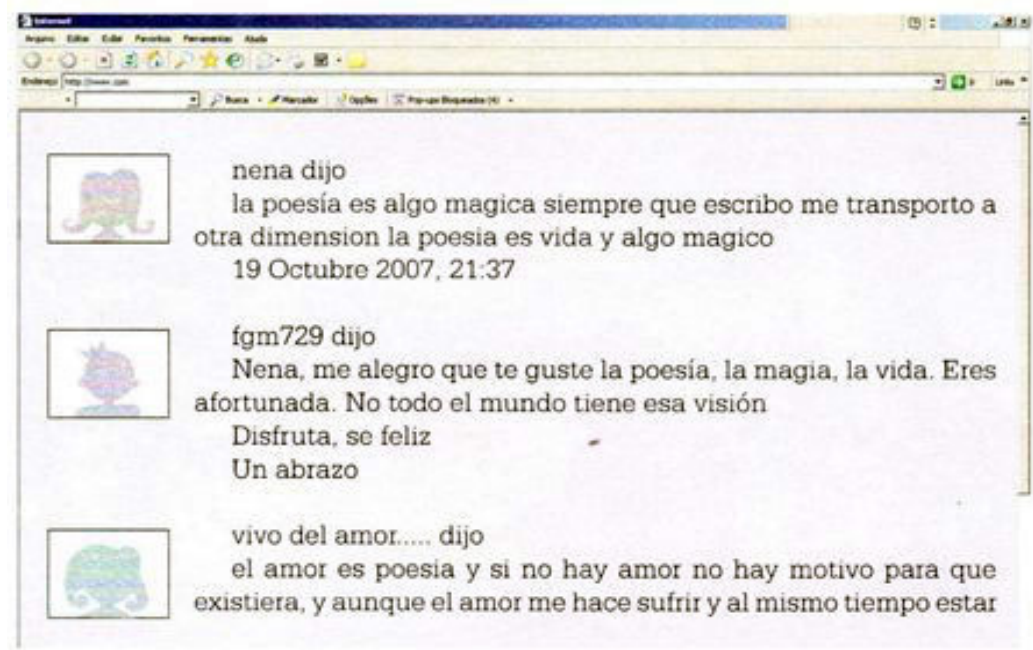

Imagem 6. Seção ;Dale! (Unidad 2)

Fonte: Picanço e Villalba (2010, p. 60) 


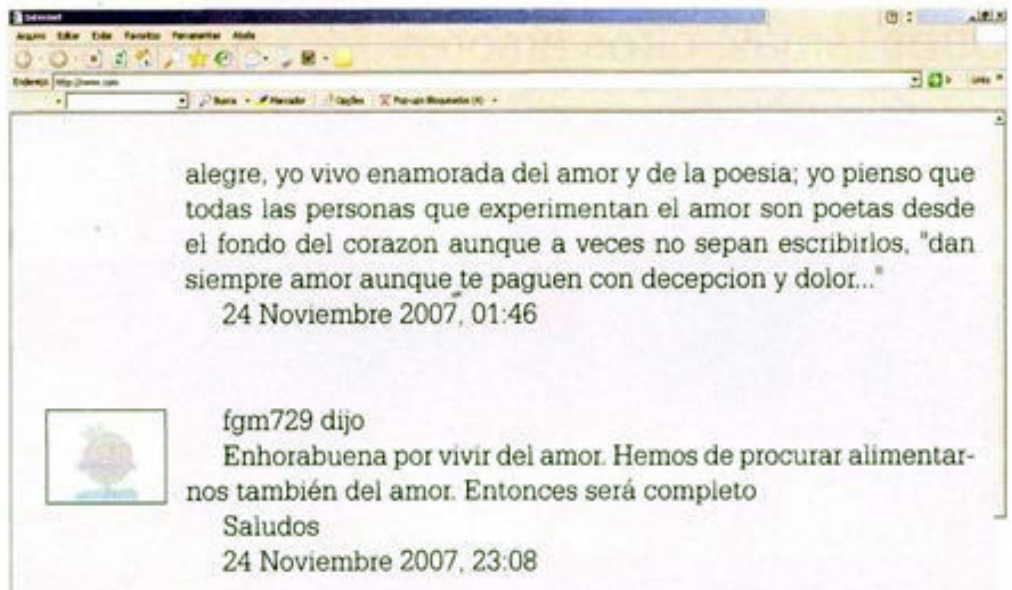

Disponible en: <http//Lacomunidad elpais,com/usuarios/tgm729> Acceso en diciembre, 2009

\section{En grupos:}

1. Observen que las palabras no tienen tilde, pues están en Internet.

2. Discutan sobre las manifestaciones de los blogueros.

3. Escriban un comentario sobre el tema para poner en el blog.

\section{ANOTACIONES}

Imagem 7. Seção ;Dale! (Unidad 2, continuação da atividade)

Fonte: Picanço e Villalba (2010, p. 61)

Nota-se na obra a permanente ausência de trabalho sobre a situação comunicativa da produção. Tampouco se explicitam os objetivos, os possíveis leitores, o papel que o aluno produtor de texto deverá assumir. Todos esses fatores inviabilizam a formação de um produtor de textos autônomo e crítico, conforme já ressaltava Geraldi (2006), e a associação entre língua e vida, segundo a concepção de linguagem do Círculo de Bakhtin (BAKHTIN, 2003; VOLÓCHINOV, 2017), pois as atividades propostas encontram-se muito distantes de práticas sociais contextualizadas.

Outrossim, não há espaço nas atividades para etapas de produção e, portanto, propostas de revisão ou reescrita são inexistentes, fator que demonstra a concepção ali presente: a escrita como um produto, não como um processo. 
Uma síntese das características encontradas nas atividades de produção escrita das coleções aprovadas no PNLD 2012 está a seguir:

- predomínio das propostas de produção a partir de gêneros, com pseudotextos presentes em apenas uma coleção (Síntesis);

- falta de indicação, na maioria absoluta das atividades, de interlocutores, tempo, espaço da finalidade da produção;

- ausência de propostas de revisão ou de reelaboração da produção textual;

- presença, na coleção Enlaces, do trabalho de apresentação do estilo e de elementos da construção composicional, embora ainda sem um aprofundamento de questões relativas à função social dos gêneros discursivos.

\subsection{PNLD 2014}

No edital de 2014, somente duas coleções alcançaram aprovação: Cercanía (COIMBRA; CHAVES, MORENO ALBA, 2012) e Formación en Español: Lengua y cultura (VILLALBA; GABARDO; MATA, 2012), ambas em primeira edição, ou seja, muito provavelmente elaboradas especificamente para submissão ao PNLD.

Segundo o Guia de Livros Didáticos do PNLD 2014 (MEC/SEB, 2013, p.13), Cercanía (COIMBRA; CHAVES, MORENO ALBA, 2012) tem um desempenho muito bom na produção escrita e Formación en Español: Lengua y cultura (VILLALBA; GABARDO; MATA, 2012), um desempenho regular.

A coleção Cercanía é de autoria de Ludmila Coimbra, Luiza Santana Chaves e José Moreno Alba. Os volumes se dividem em oito unidades e dois apêndices. A seção de escrita, denominada Escritura, se organiza em quatro subseções: Conociendo el género, Planeando las ideas, Taller de escritura e Reescritura.

$\mathrm{O}$ adendo do MP destinado à leitura do professor aborda a produção escrita na seção La enseñanza de las cuatro destrezas, mais especificamente, na subseção Escritura. Nela, afirma-se que a escrita seria um processo interativo estabelecido a partir de autor, texto, contexto de produção e receptor. O produtor seria um sujeito ativo no processo de construção de sentidos, pois escreve para ser lido por diversos leitores e, por isso, possuiria propósitos determinados. Por sua vez, a elaboração de texto, segundo o MP, deveria ser dividida por etapas: planejamento de ideias, textualização, revisão, correção, releituras e reescrita. Portanto, o proposto em termos teóricometodológicos corresponde a uma concepção de escrita como processo interativo (ELIAS, KOCH, 2009), o que se coaduna tanto com o edital do PNLD 2014, quanto com a bibliografia recente sobre escrita abordada na seção 2 deste artigo. 
Assim como consta no MP, foi verificado que a seção Escritura do LE propõe, em todas as unidades, produções de texto em gêneros discursivos extraescolares, o que é positivo e relevante. No entanto, convém ressaltar que nem sempre são gêneros que fariam parte de possíveis práticas de linguagem de escrita dos estudantes fora da escola (ANTUNES, 2003). Pode-se citar, por exemplo, a proposta de elaboração de uma campanha educativa na Unidad 3, de um poema na Unidad 5 e de uma obra de teatro na Unidad 8. Essas produções, quando ocorrem sem a ancoragem em projetos que as justifiquem, que motivem os estudantes, sem um público-alvo concreto a quem se destinem, acabam reforçando uma certa artificialidade nas práticas de escrita, aproximando-as, como afirma Geraldi (2006), de um exercício.

Outro aspecto que requer atenção diz respeito à posição que o estudante deve assumir segundo algumas propostas. Por exemplo, na Unidad 2 ele deverá escrever um bilhete para a escola posicionando-se como pai de outro estudante que não poderá ir à aula. Assim, o aluno não pode assumir-se como sujeito do seu dizer (GERALDI, 2006) e precisa simular ser outra pessoa, algo característico de métodos estruturalistas e comunicativistas do ensino de línguas adicionais.

Em todas as unidades, há um quadro indicando o gênero, o objetivo da atividade, o tema, o tipo de produção e os possíveis leitores. Isso auxilia o estudante na compreensão da situação que o texto deverá assumir e é muito relevante em uma perspectiva que entende a importância da função social do gênero discursivo como a perspectiva do Círculo de Bakhtin (BAKHTIN, 2003; VOLÓCHINOV, 2017). Cabe advertir, entretanto, que há algumas indicações vagas de leitores como, por exemplo, "estudantes" e "amantes de poemas".

Ainda que apresente alguns poucos problemas aqui mencionados, as atividades, de maneira geral, se dão de forma progressiva e processual tal como é descrito no MP, exigido no Edital do PNLD 2014 e preconizado na bibliografia recente sobre o tema abordada na seção 2. As etapas da escrita são respeitadas e desenvolvidas nas subseções de Escritura. Na maioria das vezes, explicita-se o contexto de produção e as características dos gêneros trabalhados, aproximando-se de uma perspectiva discursiva do gênero (ROJO, 2005).

É importante ressaltar que em todas as atividades há propostas de revisão e de reescrita que não somente visam a aspectos gramaticais e ortográficos, mas também ao conteúdo e a elementos textuais, vinculando o texto, mais uma vez, ao contexto de produção e ao gênero em questão. Ademais, essas propostas, na maioria das vezes, incluem outros estudantes da turma, promovendo uma atividade colaborativa. 
Convém afirmar que, até este momento, Cercanía apresenta as melhores atividades de escrita dentre as obras aprovadas no PNLD 2011, 2012 e 2014, como pode ser observado no exemplo a seguir.

\section{Escritura}

\section{Conociendo el género}

1. ¿Qué es una campana? ¿Para qué se necesita?

2. Observa una campaña de concientización de la ONG La Usina y contesta a las preguntas que siguen.

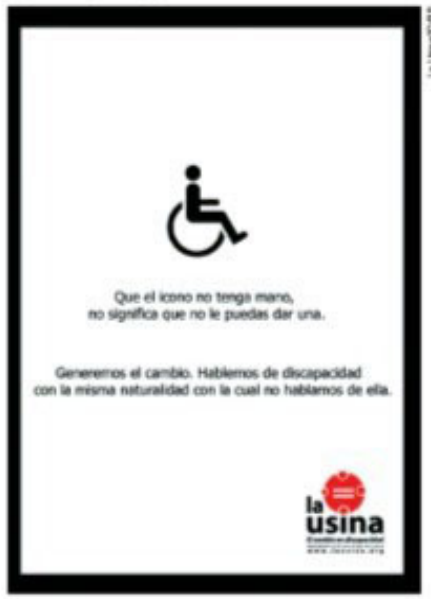

a) ¿De qué tipo de diferencia trata esa campaña?

b) ¿A quiénes se direccionan?

c] ¿Cuál es la intención de la campaña?

d) ¿Oué característica noverbal puedes observar en la campaña?

\section{$\lceil 0 j 0 !$}

Fijate que en las campahas los verbos hacen concordancia con el pronombre vos. Ejemplo: "ubica".

e) ¿Crees que las caracteristicas no verbales son fundamentales para ese tipo de campaña? ¿Por qué?

Imagem 8. Seção Escritura (Unidad 3)

Fonte: Coimbra, Chaves e Moreno Alba (2012, p. 57) 


\begin{abstract}
Planeando las ideas
Vamos a producir una campaña en defensa de "los nadies" del texto de Galeano. Vamos a nombrar a esos "nadies" en nuestra campaña como "alguiens" que tengan derechos y que merezcan respeto. ¡A planear las ideas! Como si trabajaras en la ONG La Usina, crea tres eslöganes utilizando el presente de subjuntivo, pensando en la temática de las desigualdades sociales.
\end{abstract}

Imagem 9. Seção Escritura (Unidad 3, continuação)

Fonte: Coimbra, Chaves e Moreno Alba (2012, p. 59)

\title{
Taller de escritura
}

Elige el mejor eslogan entre los tres que has creado y desarróllalo en forma de texto. Para eso, busca inspiración en el texto de Galeano, intenta ser creativo y hacer reflexionar a la gente. Luego, ilustra tu campaña con fotos e imágenes atractivas.

\section{$¡ 0 \mathrm{jo!}$}

A la hora de escribir tu campaña, piensa en el contexto de comunicación. Si quier es acercarte al lector, puedes usar un lenguaje informal, a través de los pronombres tú e vos.

Imagem 10. Seção Escritura (Unidad 3, continuação)

Fonte: Coimbra, Chaves e Moreno Alba (2012, p. 60)

\section{[Re]escritura}

Relee tu texto, checa si no hay errores y si está bien construido, si hace pensar y si defiende bien la idea de contraponerse a las desigualdades sociales. Luego, preséntaselo a todos de tu clase.

\section{Imagem 11. Seção Escritura (Unidad 3, continuação)}

Fonte: Coimbra, Chaves e Moreno Alba (2012, p. 60)

A segunda coleção aprovada no PNLD 2014, Formación en Español: Lengua y Cultura, é de Terumi Koto Bonnet Villalba - que também é uma das autoras de El arte de leer español, aprovada no PNLD 2012 -, Maristella Gabardo e Rodrigo Rodolfo R. Mata. Os volumes se dividem em quatro unidades e a parte dedicada à produção escrita é denominada Produciendo un texto propio.

No adendo teórico-metodológico do MP, o tratamento da produção textual encontra-se em uma seção também designada Produciendo un texto propio. Nela, afirmase que a escrita é de natureza interativa e processual que, por sua vez, prioriza a organização de ideias, a forma como cada um lida com novas informações e interage. Assim sendo, coaduna-se com a perspectiva de escrita com foco na interação, segundo Elias e Koch (2009).

No LE, a seção de escrita aparece em três unidades do volume, nas quais se solicita a elaboração de um texto de determinado gênero discursivo. No entanto, não há um trabalho específico quanto à situação comunicativa e, em duas unidades, as características estilísticas, composicionais e temáticas do gênero são 
pouco exploradas. Na unidade 3, que aparece como exemplo a seguir, pede-se uma publicidade turística e o trabalho pauta-se apenas na seleção de conteúdos.

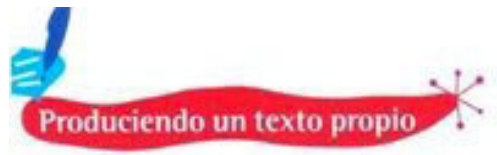

En grupos de 4 ó 5 compañeros.

1. Organicen un texto publicitario con fines de turismo cultural, siguiendo los siguientes pasos:

1.1. Elijan una de las tres rutas: la ruta de Don Quijote (personaje literario español), la ruta de la "Caatinga" (Don Quijote "cangaceiro"), o el camino del gaucho (Martin Fierro, el simbolo de las pampas).

1.2. Relean los textos anteriores y seleccionen los lugares que deben visitar: qué tipo de paisajes, qué cosas se pueden ver o visitar, qué pueden comer y qué otras opciones ofrecen: alojamiento en una casa especial, espectáculos folclóricos, productos de la tierra para degustar y comprar.

1.3. Busquen y seleccionen el material de ilustración: mapa, dibujos, fotos, fragmentos de texto de D. Quijote original, de D. Quijote nordestino o de Martín Fierro.

1.4. Escriban un texto objetivo, destacando los puntos de mayor interés.

1.5. Incluyan informaciones técnicas: cómo se llega, cuáles son los mejores hoteles, restaurantes o cafeterias, cuidados que se debe tener contra mosquitos u otros insectos, el teléfono de contacto, la página electrónica, etc.

2. Expongan el material publicitario en el mural de la escuela o de su clase.

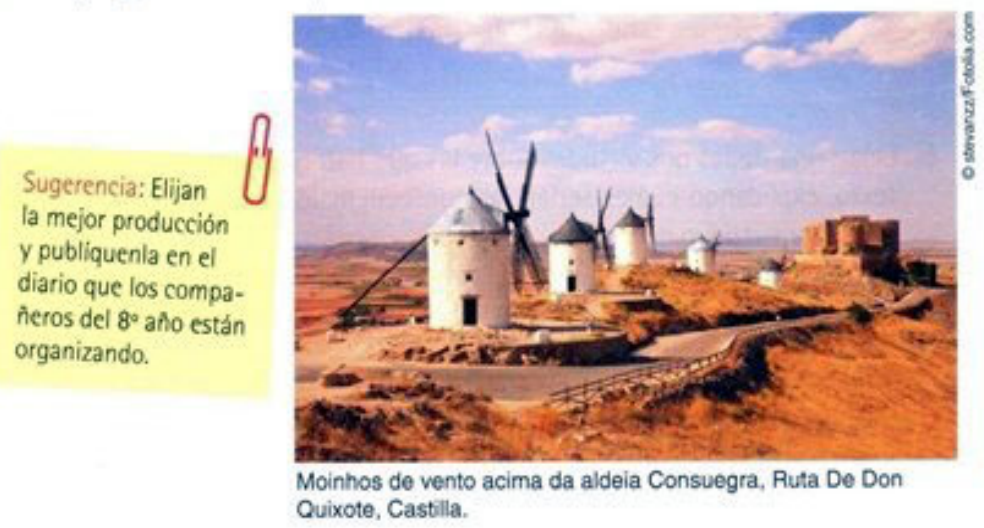

Imagem 12. Seção Produciendo un texto propio (Unidad 3)

Fonte: Villalba, Gabardo e Mata (2012, p. 90) 
A autonomia do estudante na produção de textos não é muito reforçada. Além do mais, não há uma relação significativa entre as produções e os contextos socias, o que acaba, de alguma maneira, reduzindo a produção a uma ferramenta de avaliação escolar, um exercício (GERALDI, 2006).

É importante ressaltar que as atividades não apresentam propostas de reelaboração e somente na Unidad 4 se solicita a revisão do texto.

As características encontradas nas atividades de produção escrita das duas coleções aprovadas no PNLD 2014 são as seguintes:

- solicitação de textos pertencentes a gêneros que circulam do mundo social;

- promoção do trabalho didático por etapas de produção;

- presença, em todas as atividades de escrita da coleção Cercanía, de indicação explícita do gênero, dos objetivos da atividade, do tema, do tipo de produção, dos possíveis leitores e da indicação de revisão do texto.

\subsection{PNLD 2015}

No edital do PNLD 2015 foram aprovadas também apenas duas obras de língua espanhola: Cercanía Joven (COIMBRA, CHAVES, BARCIA, 2013), cuja versão destinada ao Ensino Fundamental havia sido aprovada no PNLD 2014, e Enlaces: español para jóvenes brasileños (OSMAN et al, 2013), que já havia sido aprovada no PNLD 2012.

Cercanía Joven é de autoria de Ludmila Coimbra, Luiza Santana Chaves e Pedro Luis Barcia. Seus volumes possuem três unidades que, por sua vez, se dividem em dois capítulos. A seção de escrita está presente em três capítulos, é intitulada Escritura e se organiza em quatro subseções: Conociendo el género, Planeando las ideas, Taller de escritura e Reescritura. No Guia de Livros Didáticos do PNLD 2015 (MEC/SEB, 2014), a resenha de Cercanía Joven indica a produção escrita como um dos destaques da coleção.

No adendo teórico-metodológico do MP da coleção, o tratamento da produção de textos escritos se dá na seção Escritura. A concepção de escrita que se defende é, assim como na coleção do Ensino Fundamental, a de um processo constituído por etapas, aproximando-se da concepção com foco na interação (ELIAS, KOCH, 2009). Afirma seguir a proposta de sequência didática de Dolz, Noverraz e Schneuwly (2004), que funciona a partir da apresentação da situação, produção inicial, módulos de problemas e produção final. Há proximidade, portanto, do proposto no MP com os princípios exigidos no edital do PNLD 2015 e da visão de escrita como processo, sob um viés textual em diálogo com o discursivo. 
Na verdade, embora afirme seguir a proposta textual da Escola de Genebra, as atividades presentes no LE se aproximam mais de uma perspectiva discursiva de gêneros.

No LE, a seção exclusiva para atividades de produção também se denomina Escritura. Ela é dividida por etapas de trabalho, assim como descrito no MP da coleção, organizadas pelo conhecimento do gênero, planejamento de ideias, escrita e reescrita. Dessa forma, a escrita acontece de forma processual e permite o desenvolvimento da autonomia do estudante, dando espaço para que ele exerça um papel ativo nos textos produzidos, conforme defende Geraldi (2006), dentre outros autores mencionados na seção 2 deste artigo.

A relação com o mundo social e com os contextos de produção muitas vezes não recebe destaque; no entanto o gênero solicitado e suas características estilísticas e composicionais são apresentados nas atividades. Em especial, a atividade da seção Escritura da Unidad 3 apresenta o gênero proposto (folheto educativo) de forma muito interessante e produtiva, como pode ser visto na reprodução presente a seguir. As informações não são expostas de forma dedutiva; as questões levam os estudantes a explorarem o texto e a perceberem seu funcionamento e suas características de maneira indutiva. 


\section{$>$ Conociendo el género}

1. En la sección de lectura has leído un argumentario. ¿Cómo lo definirias? ¿Qué es un argumentario?

Según el Dikcionaris de la Regal Acodemio Espollolo, argumentario es un "Conjunto de los argumentos

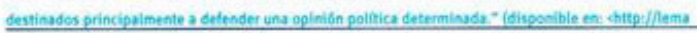

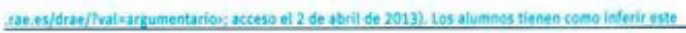
significado a traves de bs lectura que Micingen en La sección Lecturg. El arrementario contiene arrumentos. basudos en datos y fuentes confiables, o fin de informarle at lector sobre determinada trmitica.

2. La temática de tu argumentario es "Personas con discapacidad en el mundo laboral", Sigue los siguientes pasos para confeccionarlo:

a) Define qué se quiere conseguir con el argumentario.

Se trata de concinociar a ta gente sobre el enriquecimiento que supone una sociedad sin prefulcios Ademas, fomentar actitudes positivas hacia les diferenciss y promover una conciencia sociat

b) ¿A qué público va dirigido el argumentario?

Respuesta personal. Los alumnos definiran et publico objetivos los empleados de la escuela, los

empresaries, los coordinadores de la escuele, los padees y parientes, los propios alumaos, tetc

\section{El español alrededor del mundo}

El término genérico para designar a quien padece de una o más discapacidades es persona con discapacidad. En la Convención Internacional sobre los Derechos de las Personas con Discapacidad, en 2006, se lo definio ast. Términos como ciegos, sordos o discapacitados, aunque sean frecuentemente empleados. generan discusiones, ya que se pueden usarlos de forma despectiva o peyorativa. En México, el término usado es persona con capacidades diferentes, de forma a eliminar la negatividad del prefijo dis.

c) Identifica y analiza los discursos sociales del entorno sobre la inserción de las personas con discapacidad en el ambiente laboral y contesta a las preguntas a continuación:

- ¿A quiénes afecta el prejuicio en lo que respecta a la discapacidad física, a la discapacidad mental y a la discapacidad sensorial?

Vease la sección Desarrollo de les unidades y sagereacior de octinidades, en esie Maniul.

Imagem 13. Seção Escritura (Unidad 3)

Fonte: Coimbra, Chaves e Barcia (2013, p. 90)
- Género textual:

Argumentario

- Objetivo de

escritura:

Eliminar los

prejuicios

- Tema: Personas

con discapacidad

en el mundo

laboral

- Tipo de

producción: En

grupos

- Lectores:

Definido por

el grupo de los

alumnos 
- ¿Qué clase de discurso hay en la sociedad con respeto a la inserción de las personas con discapacidad en el ambiente laboral?

Es necesario registrar los comentarios frecuentes que existen en el discurso de algubos: discursos

marcadamente prejuiciosos: a) sobre la inclusich de las personas con discapacidad en el mercado de trabujo:

b) debidos al desconocimiento y mis que a una acción deliberada; c] no necesariamente pcejeiciosos, pero

Que se iefluencian sezativamente segùn el arado de influencia de otros. Ejemplos de todos esos discursos:

"Soe unos invalidos": "Hoy mucho desempleo y les discapacitades ocupan el lugar de los capacitados": "Soa

unos pobrecitos"; "No son capaces de hacer el trabajo bien hecho"; "Cuidado con lo que le solicitas: fl es

deficiente"

\section{Vocabulario en contexto}

1. El símbolo internacional de discapacidad está representado por una persona en la silla de ruedas.

Sin embargo, hay otros símbolos que representan a otros tipos de discapacidades. ¿A qué tipo de discapacidad se refiere cada símbolo a continuación? Completa cada uno con las palabras que faltan:

a)

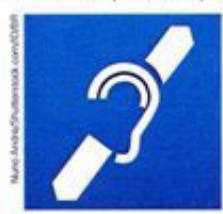

b)

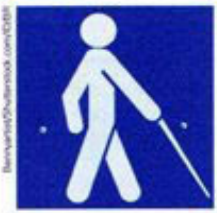

Se puede comentar la formacion de algunas palabras: sordo (sordera), ciego (ceguera), auditiv. (oudición), visual (visión), mental (mente).

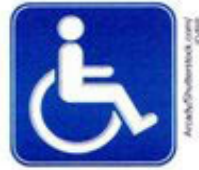

Simbolo internacional para personas con sordera o deficiencia auditiva

Simbolo internacional para personas o con discapacidad visual

cients

c)

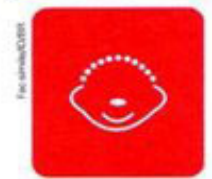

Simbolo internacional para personas con discapacidad mental

2. En el campo de las profesiones, seguro que notaste que, en el caso de la formación de la palabra, un sufijo muy usado es -ero/-era. Escribe el nombre de la persona que:
a) sirve la mesa: mesero(a) o camarerola:
b) cuida a los niños: nihero(a)
c) cuida del ganado: ganadero(a)
d) recoge la basura: basureto(a): barrendero(a)

e) ayuda a los enfermos: entermero(a)

f) prepara panes: panadero(a)

g) reparte las cartas del correo: cartero(a)

h) lleva mensajes: mensajero(a)

Imagem 14. Seção Escritura (Unidad 3, continuação)

Fonte: Coimbra, Chaves e Barcia (2013, p. 91) 


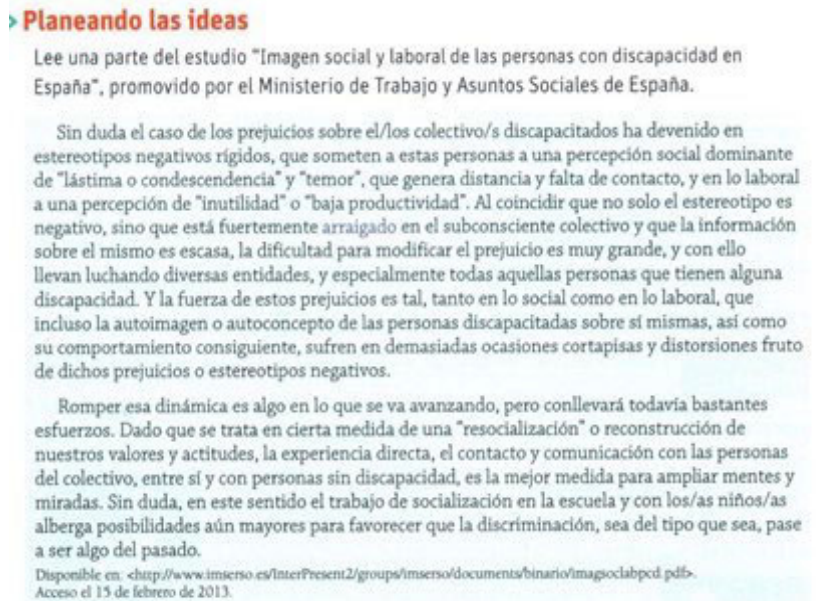

Como has podido notar, prejuicio no equivale exactamente a estereotipo. Diferencia estos dos conceptos y escríbelos en el espacio a continuación.

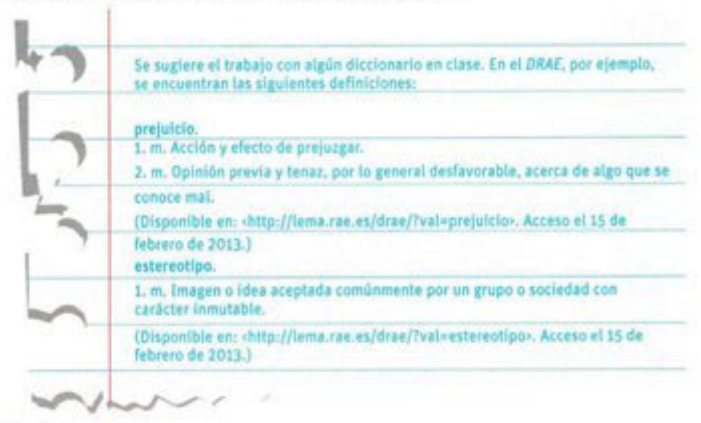

Normaimente, e esevema det estereotipes es semejante a Todos(as) los(as) son _- (adjetivos)? como por ejemplo: Todos los políticos son corrugtos", E! orefivicio tiene mis bies yn carleter infividual. cuando wa sole individis

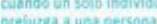
prepurzos una persone esfopidet polection, ya qoe es un Eagen etroneamente constotuda y comparti por una celectividad

A quien no to sepa

Muchas personas que sufren prejuicio luchan por romperlo. ¿Sablas que Stephen Hawking, que tiene una enfermedad degenerativa neuromuscular desde los 20 años, tiene 12 doctorados $y$ varios premios internacionales importantes? Es uno de los físicos y cosmólogos más respetados del mundo.

El fisico Stephen Hawking escribis muchos libros. Uno de los mis famosos es Una breve historia del bempo.

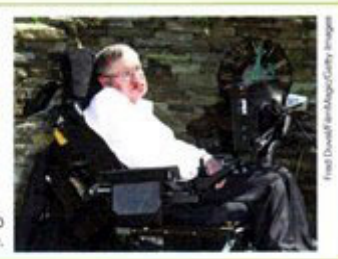

St podrian busca: informaciones sobre otras personalidades. como por ejempla yorge Luis Borges. deethoven, Aleijadin. Lars Graet, que son gersonas con aleún tip de discapacidad y que obturieron bxito en sus artes. Borges ea escritc y ciego: Beethoves era músico y sordo: Aleviadinho en esculte y tenfa discapacidad isica, Lars Grate discaoselód fisica

\section{Imagem 15. Seção Escritura (Unidad 3, continuação) Fonte: Coimbra, Chaves e Barcia (2013, p. 92)}


Taller de escritura

Para el argumentario:

1. Busca imágenes que representen la temática en discusión.

2. Elabora:

L. Un titulo para el argumentario.

II. Angumentos que pueden contrarrestar los prejuicios y estereotipos. Es aconsejable consultar articulos de prensa, estadisticas, entrevistas con expertos en discapacidades y bibliografia especializada.

\section{$\operatorname{Re}(e s c r i t u r a)$}

Relee tu argumentario y chequea si:

- pusiste datos confiables para argumentar en contra de los prejuicios;

- adecuaste el lenguaje al publico que quieres atingir:

- elegiste imagenes coherentes que ilustren adecuadamente el texto escrito;

- usaste correctamente los términos prejuicio y estereotipo.

Imagem 16. Seção Escritura (Unidad 3, continuação)

Fonte: Coimbra, Chaves e Barcia (2013, p. 93)

Todas as atividades da seção Escritura apresentam um quadro indicando o gênero, o objetivo da atividade, o tema, o tipo de produção e os possíveis leitores. Ele auxilia o estudante na representação da situação que o seu texto deverá assumir. No entanto, assim como ocorre em Cercanía, aprovado pelo PNLD 2014, algumas vezes a determinação do leitor é vaga. É o caso da produção pedida na Unidad 1, na qual os possíveis leitores seriam "internautas". Nesse caso, a indicação, além de vaga, é incoerente com o comando, pois em nenhum momento se explicita que o texto deveria ser publicado na internet.

É importante ressaltar que em todas as atividades é solicitado que o estudante revise e reescreva a sua produção, atentando não só aos aspectos gramaticais, mas a elementos textuais, discursivos e de conteúdo, conforme recomenda a bibliografia sobre o assunto apresentada na seção 2 deste artigo.

Ainda sobre a questão da revisão e da reescrita, também é importante ressaltar que na Unidad 1, suplemento Proyecto 1, é pedido que os estudantes intercambiem suas produções de forma a analisar se os efeitos esperados no leitor foram alcançados, algo que pode ser bastante produtivo e diferenciado.

A segunda coleção aprovada no PNLD 2015 é Enlaces: español para jóvenes brasileños, que também foi selecionada no PNLD 2012, mantendo a mesma editora e os mesmos autores.

Comparando as duas edições, é possível perceber que são mínimas as diferenças entre elas no que se refere à organização do MP, sua perspectiva teóricometodológica e o que se afirma sobre as propostas das atividades. 
Assim como em 2012, a seção responsável por propor atividade de escrita no LE é denominada En otras palabras, aparece em todas as unidades do livro e sempre solicita uma produção a partir de um gênero discursivo que circula no mundo social.

Os exemplos dos gêneros a serem produzidos continuam aparecendo, mas quase todos ainda são textos adaptados e dois parecem ser criados para fins didáticos: um infográfico (Unidad 7, p.123) e, especialmente, um teste de conhecimento (Unidad 8, p.139).

Também permanecem as breves explicações sobre o estilo e elementos da construção composicional do gênero. Além disso, a reflexão sobre a relação entre o gênero e o seu contexto de produção e de recepção ainda é pouco explorada.

No que se refere ao trabalho de apresentação da situação, todas as atividades se limitaram ao conteúdo e à forma do gênero. Na edição de 2012, os possíveis interlocutores e a finalidade das produções se fazem presentes, facilitando a compreensão e a produção do que é proposto.

O parco trabalho com ativação de conhecimentos sobre a situação comunicativa, já mencionado quanto à edição aprovada no PNLD 2012, permanece. Assim, a possibilidade de uma cópia dos textos de exemplo continua existindo. Dessa forma, a participação ativa do estudante pode ser pequena e distante de contextos de uso social.

Diferentemente da primeira edição analisada, é importante ressaltar que a mais recente apresenta propostas de revisão e de reelaboração em cinco unidades, conforme pode ser observado no exemplo a seguir. 


\section{En otras palabras... (ânessoo}

1. Una noticia se refiere a un acontecimiento actual, conocido o no, y presentado como verídico. El texto debe responder de forma imparcial y sintética a los interrogantes: quién, qué, cuándo, dónde, cómo y por qué. Su estilo deber ser claro, conciso y concreto.

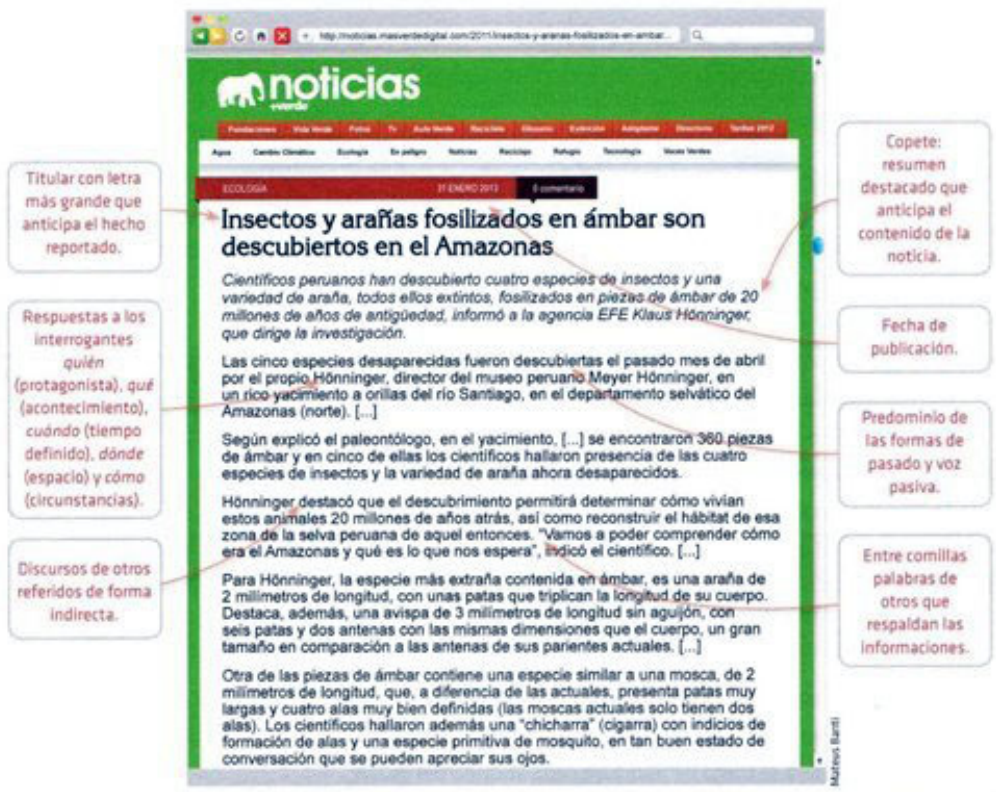

Adaptado de <noticias masverdedigital.com>. Acceso el 15 de febrero de 2013.

2. En parejas, elaboren una noticia sobre algún descubrimiento científico que consideren relevante. Para redactarla, sigan estas etapas:

a Busquen los datos que respondan a los interrogantes del hecho.

b Mencionen las fuentes consultadas para respaldar las informaciones dadas.

c Elaboren un titular que anticipe información sobre el hecho reportado.

d Hagan un borrador y pidan una primera lectura crítica a otros dos compañeros.

e Tras la lectura de sus compan̂eros, reformulen el texto y facilitenlo a los demás.

Imagem 17. Seção Escritura (Unidad 3, continuação)

Fonte: Osman et al, $(2013$, p. 71$)$

Uma síntese das características encontradas nas atividades de produção escrita das coleções aprovadas no PNLD 2015 aparece a seguir:

- solicitação de textos a partir de gêneros que circulam do mundo sociali

- proposta de trabalho por etapas de produção; 
- explicitação, na maioria das unidades, de possíveis interlocutores e da finalidade das produções;

- presença predominante de atividade de revisão e de reescrita.

\section{CONSIDERAÇÕES FINAIS}

A partir das análises realizadas, é possível afirmar que as coleções aprovadas nos editais mais recentes do PNLD, sejam elas dos anos finais do Ensino Fundamental ou do Ensino Médio, apresentaram propostas de produção escrita de qualidade substancialmente superior se comparadas às coleções distribuídas nos dois primeiros editais. Os resultados dessa breve série histórica mostram um eco gradativo da recomendação de Antenor Nascentes (1928), na segunda edição de sua Gramática da língua espanbola para uso dos brasileiros, primeiro livro de ensino de espanhol publicado no Brasil, sobre a importância de atividades de produção de textos a partir dos gêneros discursivos presentes nas possíveis práticas de escrita dos estudantes em línguas adicionais. Portanto, as coleções aprovadas nos últimos editais analisados aproximam-se do que afirma Antunes (2003) sobre a importância de produzir na escola o que se escreve fora dela, e da concepção de escrita como interação (ELIAS, KOCH, 2009).

No que se refere ao Ensino Fundamental, no PNLD 2011 as duas coleções aprovadas apresentaram diversas propostas de escrita que, na verdade, são atividades de leitura ou de gramática e não propõem a elaboração de um texto efetivo. Além disso, quando o que se pede é, de fato, uma produção, muitas vezes são solicitados pseudotextos (SOARES, 2011), ou seja, não pertencem a um gênero que circula no mundo social extraescolar. Muitas das propostas também não explicitam o possível interlocutor e a forma que deverá assumir o escrito a ser produzido. Mesmo se solicita um texto de um determinado gênero, poucas atividades realizam um trabalho da apresentação de suas características estilísticas, temáticas e composicionais e, muito menos, da situação que a produção deverá assumir, demonstrando, assim, uma frágil relação entre língua e vida, bem como pouca relevância para a formação educativa do estudante. Além disso, não há proposta alguma de revisão ou de reelaboração nas duas coleções. Portanto, a escrita é vista com foco na língua (ELIAS, KOCH, 2009).

Ainda sobre o Ensino Fundamental, no PNLD 2014 a melhora na qualidade é visível, a começar porque as duas coleções aprovadas solicitam produções em gêneros extraescolares. A coleção Cercanía, em especial, apresenta propostas de produção de forma muito alinhada ao indicado no seu MP, demonstrando coerência 
teórico-metodológica e concebendo a escrita com foco na interação (ELIAS, $\mathrm{KOCH}, 2009)$. As atividades se dão de forma progressiva e processual e as etapas de produção da escrita são respeitadas e desenvolvidas. Na maioria das vezes, explicita-se o contexto de produção e as características dos gêneros trabalhados. Além disso, apresenta proposta de revisão em todas as unidades. É relevante observar que uma atividade de escrita em Cercanía ocupa de três a quatro páginas, com várias questões para seu desenvolvimento, enquanto que em Español: !entérate!, ocupa apenas algumas linhas, como pode ser visto nos exemplos reproduzidos neste artigo, o que demonstra a diferença entre o trabalho processual do primeiro e o foco no produto do segundo.

No que tange ao Ensino Médio, no PNLD 2012 as conclusões são muito semelhantes às do PNLD 2011, de Ensino Fundamental. Como se trata do primeiro edital do programa nessa etapa de ensino, as coleções aprovadas, no geral, solicitam produções de pseudotextos (SOARES, 2011). Em sua maioria, as atividades não expõem ao estudante a finalidade da produção e a escrita é vista com foco na língua (ELIAS, $\mathrm{KOCH}, 2009)$. Além disso, não indicam os interlocutores e o papel que o estudante deverá assumir. Todos esses fatores inviabilizam a formação de um produtor de textos autônomo e crítico, bem como a associação entre língua e vida, pois as atividades propostas encontram-se muito distantes de práticas sociais contextualizadas. A coleção Enlaces se destacou, se comparada às outras duas obras aprovadas, por solicitar somente textos pertencentes a gêneros extraescolares, apresentar exemplos e se aproximar de uma perspectiva processual de escrita.

Em relação às coleções aprovadas no PNLD 2015, também do Ensino Médio, percebe-se que houve avanços significativos. Assim como nas coleções do Ensino Fundamental, a melhoria mais visível é na solicitação de produções de textos ligados a gêneros extraescolares e na ausência de pseudotextos (SOARES, 2011). Destacase a coleção Cercanía Joven que, em todas as unidades, indica o gênero, o objetivo da atividade, o tema, o tipo de produção e os possíveis leitores. Sempre há propostas de revisão e de reescrita do texto vinculando-o, mais uma vez, ao contexto de produção e ao gênero em questão. Além disso, essas propostas, na maioria das vezes, incluem outros estudantes da turma, promovendo uma atividade colaborativa. As atividades de escrita dessa coleção ocupam de quatro a oito páginas, com diversas questões para seu desenvolvimento, como pode ser observado na reprodução presente neste artigo. Quanto à coleção Enlaces, é importante ressaltar que a edição aprovada no PNLD 2015 apresenta propostas de revisão e de reelaboração também em praticamente todas as unidades. Além disso, os possíveis interlocutores e a 
finalidade das produções se fazem presentes, facilitando a compreensão do que é proposto.

Assim sendo, como já mencionado, as coleções aprovadas nos editais mais recentes apresentam um trabalho de maior qualidade em uma compreensão mais próxima à da escrita como um processo interativo que envolve a mobilização de inúmeros saberes linguísticos, genéricos e de mundo. De alguma forma, isso demonstrou uma disposição a atender não somente aos editais do PNLD aos quais foram submetidas, mas principalmente a se aproximar dos propósitos e finalidades da Educação Linguística em Línguas Adicionais.

Cabe concluir este artigo citando a exclusão da língua espanhola não somente dos editais do PNLD, conforme já se viu no PNLD 2020 (MEC/FNDE/SEB, 2018), mas da Educação Básica, em função da retirada do componente curricular Língua Estrangeira Moderna da Lei de Diretrizes e Bases da Educação Nacional pela Lei 13.415 (BRASIL, 2017a). Tal fato compromete a continuidade desta e de outras pesquisas sobre livros didáticos de espanhol, além de afetar projetos que envolvem a presença dessa língua nas escolas e a pluralidade linguístico-cultural da educação linguística em línguas adicionais.

\section{REFERÊNCIAS}

ALBUQUERQUE, C. T. (2019). Livros didáticos de espanbol na década de 1940: concepção de língua e concepção de escrita. Dissertação de Mestrado em Estudos de Linguagem. Instituto de Letras, UFF, Niterói.

ANTUNES, I. Aula de português: encontro e interação, $1^{a}$ ed. São Paulo: Parábola Editorial, 2003.

ARROYO, M. (2012). O direito a tempos-espaços de um justo e digno viver. In: MOLL, J. (org.). Caminhos da Educação Integral no Brasil: direito a outros tempos e espaços educativos. Porto Alegre: Penso, p. 33-45.

BAKHTIN, M. (1979). Estética da criação verbal, $1^{\text {a }}$ ed., trad. Paulo Bezerra. São Paulo: Martins Fontes, 2003.

BRASIL (1985). Decreto $n^{0}$ 91.542, de 19 de adosto de 1985. Disponível em: <https://www2. camara.leg.br/legin/fed/decret/1980-1987/decreto-91542-19-agosto-1985-441959publicacaooriginal-1-pe.html > . Acesso em: 20 mar. 2019. 
BRASIL (2016). Medida Provisória $n^{0}$ 746, de 22 de setembro de 2016. Disponível em: < http://www. planalto.gov.br/ccivil 03/Ato2015-2018/2016/Mpv/mpv746.htm >. Acesso em: 30 set. 2016.

BRASIL (2017a). Lei $n^{0}$ 13.415, de 16 de fevereiro de 2017. Disponível em: < http://www.planalto. gov.br/ccivil 03/ Ato2015-2018/2017/Lei/L13415.htm>. Acesso em: 2 mar. 2017.

BRASIL (2017b). Decreto no 9.099, de 18 de julho de 2017. Disponível em: < http://www. planalto.gov.br/ccivil_03/_Ato2015-2018/2017/Lei/L13415.htm > . Acesso em: 20 jul. 2017.

BRASIL (2013). Ministério da Educação. Diretrizes Curriculares Nacionais Gerais da Educação Básica. Brasília: MEC, SEB, DICEI, 2013.

BRUNO, F. A.; ARRUDA, S. A. F.; TONI, M. A. M. B. (2009). Español: ientérate!, $3^{\text {a }}$ ed. São Paulo: Saraiva, 2009, v. $9^{\circ}$ ano, Manual do Professor.

BUNZEN, C. (2006). Da era da composição à era dos gêneros: o ensino de produção de texto no ensino médio. In: BUNZEN, C.; MENDONÇA, M. (org.). Português no ensino médio e formação do professor, $1^{\text {a }}$ ed. São Paulo: Parábola Editorial.

CAMPOS, T. S. (2016). Propostas de expressão escrita nos livros didáticos do PNLD 2012 e 2015: o que mudou? Dissertação de Mestrado em Estudos Lingüísticos. Faculdade de Letras, UFMG, Belo Horizonte.

CAPES (2019). Catálogo de teses e dissertações. Disponível em: < http://catalogodeteses.capes. gov.br>. Acesso em: 10 fev. 2019.

CARNEIRO, C. F. S.; COSTA, E. G. M.;FERNANDES, K. C. (2015). Leitura e escrita de gêneros textuais em livro didático de espanhol. Linguagem \& Ensino, Pelotas-RS, v. 18, n. 2, p. 379-402.

CASSIANO, C. C. F. (2007). O mercado do livro didático no Brasil: do Programa Nacional do Livro Didático - PNLD à entrada do capital internacional espanbol (1985-2007). Tese de Doutorado em Educação. PUCSP, São Paulo.

COIMBRA, L; CHAVES, L. S.; MORENO ALBA, J. (2012). Cercanía: español, $1^{\text {a }}$ ed. São Paulo: Ed. SM, v. 4, Manual do Professor.

COIMBRA, L; CHAVES, L. S.; BARCIA, P. L. (2013). Cercanía joven: español, $1^{\text {a }}$ ed. São Paulo: Ed. SM, v. 3, Manual do Professor. 
DOLZ, J.; SCHNEUWLY, B.; NOVERRAZ, M. (2004). Gêneros orais e escritos na escola. In: SCHNEUWLY, B.; DOLZ, J. Gêneros orais e escritos na escola, $1^{\text {a }}$ ed, trad. e org. Roxane Rojo e Glaís Sales Cordeiro. Campinas, SP: Mercado de Letras, p. 215-246.

ELIAS, V.; KOCH, I. (2009). Ler e escrever: estratégias de produção textual, $1^{\text {a }}$ ed. São Paulo: Contexto.

FNDE (2019). Livro Didático. Disponível em: < http://www.fnde.gov.br/programas/livrodidatico/>. Consulta em: 30 abr. 2019.

FREIRE, P. (1981). A importância do ato de ler: em três artigos que se completam, 23 a ed. São Paulo: Autores Associados: Cortez, 1989.

FREITAS, L.M.A.; VARGENS, D.P.M. (2010). Ler e escrever: muito mais que unir palavras. In: BARROS, C.S.; COSTA, E.G.M. (Org.). Espanbol: ensino médio. Brasília: Ministério da Educação, Secretaria de Educação Básica, v. 16, p. 191-220.

FREITAS, L.M.A.; DAHER, D.C. ; SANT’ANNA, V.L.A. (2013). Breve trajetória do processo de avaliação do livro didático de língua estrangeira para a educação básica no âmbito do PNLD. Eutomia, v. 1, p. 407-426.

FREITAS, L.M.A.; VARGENS, D.P.M. (2016). Libros de texto de español en Brasil: qué actividades proponen para la producción escrita? In: NARVAJA DE ARNOUX, E.; LAURIA, D. (Org.). Lenguas y discursos en la construcción de la ciudadanía sudamericana. Gonnet/Buenos Aires: Unipe: Editorial Universitaria, p. 41-57.

FREITAS, L.M.A.; COSTA, E.G.M.; BARROS, C. S. (Org.) (2018). O livro didático de espanbol na escola brasileira. Campinas: Pontes.

GERALDI, J.W. (org.) (1984). O texto na sala de aula: leitura e produção, $4^{\text {a }}$ ed. São Paulo: Ática, 2006.

GERALDI, J.W. (1991). Portos de Passagem, $3^{\text {a }}$ ed. São Paulo: Martins Fontes, 1995.

LAJOLO, M. (1982). O texto não é pretexto. In: ZILBERMAN, R. (org.). Leitura em crise na escola: as alternativas do professor. Porto Alegre: Mercado Aberto, p. 51-62.

MARCUSCHI, B. (2010). Escrevendo na escola para a vida. In: RANGEL, E. O.; ROJO, R. (Org.). Língua Portuguesa. Brasília: Ministério da Educação, Secretaria de Educação Básica, Coleção Explorando o Ensino, v. 19. 
MARTIN, I. (2009). Saludos - curso de lengua española, 1ª ed. São Paulo: Ática, 2009, v. 4, Manual do Professor.

MARTIN, I. (2010). Síntesis - curso de lengua española, $1^{\text {a }}$ ed. São Paulo: Ática, 2010, v. 3, Manual do Professor.

MEC/FNDE/SEB (2005). Edital de convocação para inscrição no processo de seleção de material didático da língua espanbola para professores do ensino médio. Brasília: MEC/FNDE/SEB.

MEC/FNDE/SEB (2008). Edital de convocação para inscrição no processo de avaliação e seleção de coleções didáticas para o Programa Nacional do Livro Didático - PNLD 2011. Brasília: MEC/FNDE/ SEB.

MEC/FNDE/SEB (2009). Edital de convocação para inscrição no processo de avaliação e seleção de coleções didáticas para o Programa Nacional do Livro Didático - PNLD 2012. Brasília, MEC/FNDE/ SEB.

MEC/FNDE/SEB (2011). Edital de convocação para inscrição no processo de avaliação e seleção de coleções didáticas para o Programa Nacional do Livro Didático - PNLD 2014. Brasília, MEC/FNDE/ SEB.

MEC/FNDE/SEB (2013). Edital de convocação para inscrição no processo de avaliação e seleção de coleções didáticas para o programa nacional do livro didático - PNLD 2015. Brasília, MEC/FNDE/SEB.

MEC/FNDE/SEB (2018). Edital de convocação para inscrição no processo de avaliação e seleção de coleções didáticas para o programa nacional do livro didático - PNLD 2020. Brasília, MEC/FNDE/SEB.

MEC/SEB (2010). Guia de livros didáticos: PNLD 2011: Língua Estrangeira Moderna. Brasília: Ministério da Educação, Secretaria de Educação Básica.

MEC/SEB (201manua1). Guia de livros didáticos: PNLD 2012: Língua Estrangeira Moderna. Brasília: Ministério da Educação, Secretaria de Educação Básica.

MEC/SEB (2013). Guia de livros didáticos: PNLD 2014: Língua Estrangeira Moderna. Brasília: Ministério da Educação, Secretaria de Educação Básica.

MEC/SEB (2014). Guia de livros didáticos: PNLD 2015: Língua Estrangeira Moderna. Brasília: Ministério da Educação, Secretaria de Educação Básica.

NASCENTES, A. (1920). Gramática da língua espanbola para uso dos brasileiros, $2^{\mathrm{a}}$ ed. Rio de Janeiro: Pimenta de Mello \& C., 1928. 
OSMAN, S. et al (2007). Enlaces: español para jóvenes brasileños, $2^{\text {a }}$ ed. São Paulo: Macmillan, 2010, v. 3, Manual do Professor.

OSMAN, S. et al (2007). Enlaces: español para jóvenes brasileños, $3^{\mathrm{a}}$ ed. São Paulo: Macmillan, 2013, v. 3, Manual do Professor.

PICANÇO, D. C. L; VILLANBA, T. K. B. (2006). El arte de leer español, $2^{\mathrm{a}}$ ed. Curitiba: Base Editorial, 2010, v. 3, Manual do Professor.

ROJO, R.; CORDEIRO, G. S. (2004). Apresentação: gêneros orais e escritos como objetos de ensino - modo de pensar, modo de fazer. In: SCHNEUWLY, B.; DOLZ, J. Gêneros orais e escritos na escola, $1^{\text {a }}$ ed., trad. e org. Roxane Rojo e Glaís Sales Cordeiro. Campinas: Mercado de Letras, p. 7-18.

ROJO, R. (2005). Gêneros do discurso e gêneros textuais: questões teóricas e aplicadas. In: MEURER, J.L.; BONINO, A.; MOTTA-ROTH, D. (org.). Gêneros: teorias, métodos, debates. São Paulo: Parábola.

SILVÉRIO, B. M. S. (2019). Os brasileiros e os não brasileiros nos livros didáticos de espanbol: uma análise discursiva sobre as identidades. Tese de Doutorado em Estudos de Linguagem. Instituto de Letras, UFF, Niterói.

SOARES, M. (2011). A escolarização da literatura infantil e juvenil. In: EVANGELISTA, A.A.M.; BRANDÃO, H.M.B.; MACHADO, M.Z.V. (orgs.). Escolarização da leitura literária. $2^{\mathrm{a}}$ ed., $3^{\mathrm{a}}$ reimp. Belo Horizonte: Autêntica.

TEIXEIRA, M. E. S. (2016). A produção escrita nos livros didáticos de língua espanbola aprovados no PNLD 2015. Dissertação de Mestrado Profissional em Formação de Professores da Educação. UESC, Ilhéus.

VAZQUEZ, R.P.; FREITAS, L.M.A. (2017). Língua Estrangeira e Língua Portuguesa no edital do PNLD 2011: aproximações e distanciamentos. Cadernos da Educação Básica, v. 2, p. 1-26.

VILLALBA, T. K. B.; GABARDO, M.; MATA, R. R. R. (2012). Formación en Español: lengua y cultura, $1^{\text {a }}$ ed. Curitiba: Base Editorial, v. $9^{\circ}$ ano, Manual do Professor.

VOLÓCHINOV, V. (1929). Marxismo e filosofia da linguagem. Problemas fundamentais do método sociológico na ciência da linguagem, $1^{\mathrm{a}}$ ed., trad., notas e glossário de S. Grillo e E. Vólkova Américo, ensaio introdutório de Sheila Grillo. São Paulo: Editora 34, 2017.

Recebido: $11 / 06 / 2019$

Aceito: $1 / 10 / 2019$

Publicado: 4/10/2019 